\title{
Comparison of $\mathrm{CO}_{2}$ and $\mathrm{O}_{2}$ fluxes demonstrate retention of respired $\mathrm{CO}_{2}$ in tree stems from a range of tree species
}

\author{
Boaz Hilman ${ }^{1, a}$, Jan Muhr ${ }^{2}$, Susan E. Trumbore ${ }^{2}$, Norbert Kunert ${ }^{2}$, Mariah S. Carbone ${ }^{3}$, Päivi Yuval ${ }^{4,5}$, \\ S. Joseph Wright ${ }^{6}$, Gerardo Moreno ${ }^{7}$, Oscar Pérez-Priego ${ }^{8}$, Mirco Migliavacca ${ }^{8}$, Arnaud Carrara $^{9}$, \\ José M. Grünzweig ${ }^{4}$, Yagil Osem ${ }^{5}$, Tal Weiner ${ }^{1}$, and Alon Angert ${ }^{1}$ \\ ${ }^{1}$ The Fredy and Nadine Herrmann Institute of Earth Sciences, the Hebrew University of Jerusalem, Jerusalem, 91940, Israel \\ ${ }^{2}$ Department of Biogeochemical Processes, Max Planck Institute for Biogeochemistry, 07745 Jena, Germany \\ ${ }^{3}$ Center for Ecosystem Science and Society, Northern Arizona University, Flagstaff, AZ 86011, USA \\ ${ }^{4}$ Robert H. Smith Institute of Plant Sciences and Genetics in Agriculture, Robert H. Smith Faculty of Agriculture, \\ Food and Environment, the Hebrew University of Jerusalem, Rehovot, 76100, Israel \\ ${ }^{5}$ Institute of Plant Sciences, Agricultural Research Organization, Volcani Center, Bet Dagan, 50250, Israel \\ ${ }^{6}$ Smithsonian Tropical Research Institute, Balboa, Apartado 0843-03092, Panama \\ ${ }^{7}$ Institute for Dehesa Research, University of Extremadura, 10600 Plasencia, Spain \\ ${ }^{8}$ Department of Biogeochemical Integration, Max Planck Institute for Biogeochemistry, 07745 Jena, Germany \\ ${ }^{9}$ Instituto Universitario Fundación Centro de Estudios Ambientales del Mediterráneo (CEAM-UMH), 46980 Paterna, Spain \\ a current address: Department of Biogeochemical Processes, Max Planck Institute for Biogeochemistry, 07745 Jena, Germany
}

Correspondence: Boaz Hilman (boaz.hilman@gmail.com)

Received: 30 May 2018 - Discussion started: 25 June 2018

Revised: 3 December 2018 - Accepted: 3 January 2019 - Published: 17 January 2019

\begin{abstract}
The ratio of $\mathrm{CO}_{2}$ efflux to $\mathrm{O}_{2}$ influx (ARQ, apparent respiratory quotient) in tree stems is expected to be 1.0 for carbohydrates, the main substrate supporting stem respiration. In previous studies of stem fluxes, ARQ values below 1.0 were observed and hypothesized to indicate retention of respired carbon within the stem. Here, we demonstrate that stem ARQ $<1.0$ values are common across 85 tropical, temperate, and Mediterranean forest trees from nine different species. Mean ARQ values per species per site ranged from 0.39 to 0.78 , with an overall mean of 0.59 . Assuming that $\mathrm{O}_{2}$ uptake provides a measure of in situ stem respiration (due to the low solubility of $\mathrm{O}_{2}$ ), the overall mean indicates that on average $41 \%$ of $\mathrm{CO}_{2}$ respired in stems is not emitted from the local stem surface. The instantaneous ARQ did not vary with sap flow. ARQ values of incubated stem cores were similar to those measured in stem chambers on intact trees. We therefore conclude that dissolution of $\mathrm{CO}_{2}$ in the xylem sap and transport away from the site of respiration cannot explain the low ARQ values. We suggest refixation of respired $\mathrm{CO}_{2}$ in biosynthesis reactions as possible mechanism for low ARQ values.
\end{abstract}

\section{Introduction}

The global annual $\mathrm{CO}_{2}$ efflux from tree stems to the atmosphere is estimated at 6.7 $\pm 1.1 \mathrm{Pg} \mathrm{C} \mathrm{yr}^{-1}$ (Yang et al., 2016), but the drivers of stem $\mathrm{CO}_{2}$ efflux are not well understood (Trumbore et al., 2013). $\mathrm{CO}_{2}$ in tree stems originates primarily from aerobic respiration, which consumes oxygen $\left(\mathrm{O}_{2}\right)$. The respiratory quotient (RQ) is defined as the ratio between $\mathrm{CO}_{2}$ produced and $\mathrm{O}_{2}$ consumed, and its value is derived from the stoichiometry of the metabolized substrate. Carbohydrates are believed to be the main respiratory substrate in tree stems (Hoch et al., 2003; Plaxton and Podestá, 2006), and their metabolism results in an RQ of $\sim 1.0$. Respiration that relies entirely on lipids predicts $\mathrm{RQ}$ values of $\sim 0.7$, but it is not clear to what extent lipids are stored and used in trees as they are rarely measured (Hartmann and Trumbore, 2016). Current understanding suggests that significant storage of lipids in stems is uncommon and limited to several tree genera, the so-called "fat trees" (Sinnott, 1918). RQ values greater than 1.0 are associated with organic acids catabolism, due to the greater $\mathrm{O}$ content of the molecules being oxi- 
dized. For these reasons, we expect principally carbohydrate metabolism in tree stems and an RQ of approximately 1.0.

Initial measurements of the ratio of $\mathrm{CO}_{2}$ efflux to $\mathrm{O}_{2}$ influx from the stem surface for six tree species found values mostly below 1.0 (Angert and Sherer, 2011; Angert et al., 2012). The flux ratio is referred to in those studies, and here, as the "apparent" RQ (ARQ), because it potentially includes additional sources or sinks of $\mathrm{CO}_{2}$ and/or $\mathrm{O}_{2}$ in the stem in addition to the respiration taking place in tissue beneath a chamber placed on the stem surface. Processes that can potentially reduce the emission of $\mathrm{CO}_{2}$ and thereby decrease ARQ below 1.0 include (1) dissolution and transport of $\mathrm{CO}_{2}$ in the xylem sap (Teskey et al., 2008), and (2) carboxylating reactions during biosynthesis of compounds more oxidized than carbohydrates that involve refixation of $\mathrm{CO}_{2}$ by the enzyme phosphoenolpyruvate carboxylase (PEPC) (Lambers et al., 2008). Alternatively, it may be hypothesized that ARQ below 1.0 is the result of non-respiratory $\mathrm{O}_{2}$ uptake, e.g., by oxidases and hydroxylases that are $\mathrm{O}_{2}$-consuming enzymes.

Carbon dioxide is $\sim 30$ times more soluble in water than $\mathrm{O}_{2}$, and dissolved $\mathrm{CO}_{2}$ reacts with water to form bicarbonate $\left(\mathrm{HCO}_{3}^{-}\right)$and carbonate $\left(\mathrm{CO}_{3}^{2-}\right)$ ions, further increasing the amount of dissolved inorganic carbon (DIC). The rate of $\mathrm{O}_{2}$ uptake is thus assumed to provide a better measure of stem respiration than $\mathrm{CO}_{2}$ efflux, which can be complicated by dissolution and transport within the xylem sap (Teskey et al., 2008), potentially contributing to low ARQ values. There is evidence from studies with an isotopically labeled stem $\mathrm{CO}_{2}$ pool that a significant portion of $\mathrm{C}$ is transported as DIC to photosynthetic tissues where it might be refixed to organic C (Bloemen et al., 2013; McGuire et al., 2009; Powers and Marshall, 2011). If transport of $\mathrm{CO}_{2}$ within the stem is important, ARQ measured at the stem surface is expected to be inversely related to sap velocity. As the difference in solubility between $\mathrm{CO}_{2}$ and $\mathrm{O}_{2}$ decreases with increasing temperature (Gevantman, 2018), ARQ also might be expected to increase with temperature if all other factors remain constant. In addition, variations of ARQ with stem height are to be expected. A model of $\mathrm{CO}_{2}$ diffusion and advection in the xylem sap by Hölttä and Kolari (2009) predicted that the accumulation of dissolved $\mathrm{CO}_{2}$ in the ascending xylem sap, together with a reduction in stem diameter with height, induces faster $\mathrm{CO}_{2}$ diffusive loss to the atmosphere in the upper parts of the stem. Thus, we expect an increase in ARQ (higher $\mathrm{CO}_{2}$ loss per mole of $\mathrm{O}_{2}$ uptake) with stem height if dissolution and transport of $\mathrm{CO}_{2}$ in the xylem sap is important.

The second possible explanation for low ARQ is local dark refixation in the stem by PEPC (Angert et al., 2012). PEPC is present in tree stems (Berveiller and Damesin, 2008; Höll, 1974; Ivanov et al., 2005), and its activity was suggested to be sufficient to have a measurable impact on respired $\mathrm{CO}_{2}$ in Ricinus communis (Gessler et al., 2009). Stem ARQ values would remain below unity as long as the products of PEPC fixation (e.g., malate and citrate) are not inhibiting further fixation. To date, studies of these processes in large trees are scarce, and it is not clear which processes are responsible for low ARQ. If ARQ values lower than unity are prevalent and result from processes that retain $\mathrm{CO}_{2}$ in the stem, estimates of tree stem respiration based on $\mathrm{CO}_{2}$ efflux measurements must be reconsidered. Thus, the first objective of this work is to determine whether ARQ values lower than 1.0 are observed in a variety of trees from different biomes and across seasons. A secondary objective of this study is to test whether ARQ varies with xylem stream characteristics or with tree height.

\section{Materials and methods}

\subsection{Methods for evaluating ARQ}

We report tree stem ARQ results based on measurement methods described in Hilman and Angert (2016). These methods overcome the difficulty of measuring small changes in $\mathrm{O}_{2}$ against the high atmospheric background by using a static stem chamber, in which the $\mathrm{O}_{2}$ changes are considerably larger than in an open flow chamber.

We used three different approaches to measuring ARQ: two are based on discrete gas samples of headspace air, and one is based on direct measurement of the headspace air using gas sensors ("continuous" sampling). Discrete gas samples are either taken within $30 \mathrm{~min}$ to several hours after chamber sealing ("instantaneous" sampling) or after the chamber has been sealed to the stem for more than $24 \mathrm{~h}$, once steady-state conditions have been achieved ("steady state"). These methods and the time required for achieving steady state were confirmed by comparing with continuous measurements (Hilman and Angert, 2016). For each site and experiment described in Sect. 2.2, we identify the method used to estimate ARQ as instantaneous, steady state (for flask samples), or continuous (Table 1).

\subsubsection{ARQ measurement from discrete samples}

The evaluation of ARQ from discrete gas measurements is based on a one-box model that describes gas dynamics in the headspace of a static chamber sealed to the surface of a tree stem (Angert and Sherer, 2011; Angert et al., 2012; Hilman and Angert, 2016). In the model, the gas in the chamber headspace has initial mean atmospheric values $\left(20.95 \% \mathrm{O}_{2}\right.$, $0.04 \% \mathrm{CO}_{2}$ ), ensured by flushing the chamber with ambient air before measurement. Once the chamber is closed and the headspace above the stem surface is isolated, metabolic reactions in the stem control the chamber's air composition. For the first few hours, headspace concentrations of $\mathrm{CO}_{2}$ increase and $\mathrm{O}_{2}$ decrease at rates that are roughly linear with time (instantaneous incubation, Figs. 1 and S1 in the Supplement). During this linear stage, ARQ is calculated by

$$
\mathrm{ARQ}=\frac{\mathrm{CO}_{2} \text { efflux }}{\mathrm{O}_{2} \text { influx }}=\frac{\Delta \mathrm{CO}_{2}}{\Delta \mathrm{O}_{2}},
$$


Table 1. Study sites, tree species sampled at each site, stem chambers, stems diameters, and experiments done in the site (A-G list in Sect. 2.2).

$\begin{array}{llll}\text { Site and coordinates } & \text { Species } & \begin{array}{l}\text { Chamber } \\ \text { type, sealant }\end{array} & \begin{array}{l}\text { Stem diameter } \\ (\mathrm{cm}, \text { mean } \pm \mathrm{SD} \text { Experiments in the site (as listed in } \\ (n))^{\mathrm{a}}\end{array}\end{array}$

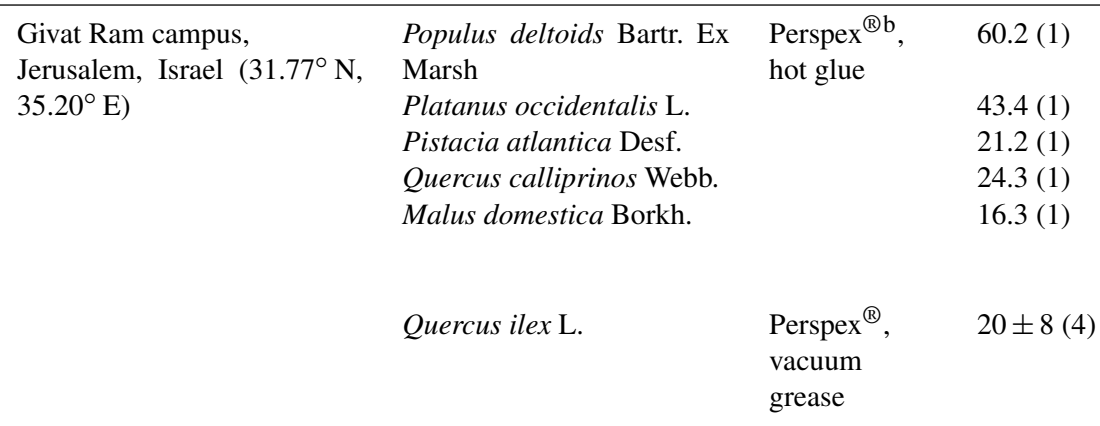

\begin{tabular}{lll}
\hline Ramat Hanadiv Nature & Quercus calliprinos Webb. & $\begin{array}{l}\text { Perspex } \\
\text { glue }\end{array}$ \\
Park, harmel Ridge, Israel & & $11.2 \pm 1.2(4)$ \\
$\left(32.55^{\circ} \mathrm{N}, 34.94^{\circ} \mathrm{E}\right)$ & &
\end{tabular}
Seasonal and phenological measurements (A) and vertical transects for $P$. occidentalis and $Q$. calliprinos $(\mathrm{F})$ - every $1-3$ months between July 2011 and July 2014 (s, i). Day-night variation (C) - July 2012 and April 2013 (i). Day-night variation (C) and temperature effect on ARQ for the $M$. do- mestica (D) - April 2013 (c).

Comparison between stem chambers and incubated stem cores ARQ, and repeated incubations of stem cores and leaves $(\mathrm{G})$ July 2016 (s, i).

Park, Carmel Ridge, Israel $\left(32.55^{\circ} \mathrm{N}, 34.94^{\circ} \mathrm{E}\right)$

\begin{tabular}{ll}
\hline Bartlett Experimental For- Acer rubrum L. & Polypropylene $^{\mathrm{c}}, 20 \pm 10(4)$ \\
est, NH, USA $\left(44.06^{\circ} \mathrm{N}\right.$, & caulking \\
$\left.71.29^{\circ} \mathrm{W}\right)$ &
\end{tabular}

Simultaneous measurements of ARQ and predawn shoot water potential (E) April 2012, September 2012, and January 2013 (s).

\begin{tabular}{ll}
\hline $\begin{array}{l}\text { Harvard Forest, MA, USA Acer rubrum L. } \\
\left(42.53^{\circ} \mathrm{N}, 72.17^{\circ} \mathrm{W}\right)\end{array}$ & $\begin{array}{l}\text { Polypropylene, } 18 \pm 9(3) \\
\text { caulking }\end{array}$
\end{tabular}

Comparison to Harvard Forest based on dif-
ferent phenology (A) - September 2012.

\begin{tabular}{|c|c|c|c|}
\hline $\begin{array}{l}\text { Majadas de Tiétar, Cáceres, } \\
\text { Spain }\left(39^{\circ} 56^{\prime} 25^{\prime \prime} \mathrm{N},\right. \\
\left.5^{\circ} 46^{\prime} 28^{\prime \prime} \mathrm{W}\right)\end{array}$ & Quercus ilex $\mathrm{L}$. & $\begin{array}{l}\text { Perspex }^{\circledR}, \\
\text { vacuum } \\
\text { grease }\end{array}$ & $45 \pm 7(16)$ \\
\hline
\end{tabular}
Comparison to Bartlett Experimental Forest based on different phenology (A) - Septem- ber 2012.
Simultaneous measurements of ARQ and sap flux density (B) and comparison be- tween stem chambers and incubated stem cores ARQ (G) - May 2015 (s, i).

\begin{tabular}{llll}
\hline Gigante peninsula, Barro & Tetragastris panamensis & $\begin{array}{l}\text { Perspex } \\
\text { ( }\end{array}$ & $30.0 \pm 12.5(42)$ \\
vacuum & grease \\
ment, Republic of Panama & (Engl.) Kuntze & grease Nare Monu- \\
$\left(9^{\circ} 06^{\prime} 31^{\prime \prime} \mathrm{N}, 79^{\circ} 50^{\prime} 37^{\prime \prime} \mathrm{W}\right)$ & &
\end{tabular}
Comparison between stem chambers and incubated stem cores ARQ (G) - September-October 2013 (s). Addi- tional stem chamber ARQ measurements - September 2012, September-October 2013, and March-April 2014 (s, i).

A station of the Brazilian Na-
tional Institute for
Research in the Amazon
(INPA), northwest of Man-
aus, Brazil $\left(2^{\circ} 38^{\prime} 23^{\prime \prime} \mathrm{S}\right.$,
$\left.60^{\circ} 09^{\prime} 51^{\prime \prime} \mathrm{W}\right)$

Scleronema micranthum $\quad$ Polypropylene $^{\mathrm{d}} 41.2 \pm 13.3$ (7)
(Ducke) Ducke

Seasonal variability (A) - five campaigns between March 2012 and March 2014 (six trees) ( $\mathrm{i}$ in the two first campaigns, $\mathrm{s}$ in the three later campaigns). Vertical transects including in-stem measurements $(\mathrm{F})$ - March and October 2012 (i). Comparison between stem chambers and incubated stem cores ARQ (G) - March 2014 (s).

\footnotetext{
a All chambers were installed at $\sim 1.3 \mathrm{~m}$ above the ground, except for the $Q$. calliprinos on Carmel Ridge that were placed near to the ground due to the shrubby canopy, the low branching of the trunk, and the constraint of the size of the chamber. ${ }^{b}$ Chambers were made of a $10 \mathrm{~cm} \times 12 \mathrm{~cm}$ Perspex ${ }^{\circledR}$ plate with four connectors to allow attachment of sampling flasks. The chamber on the $M$. domestica was slightly larger, $12 \mathrm{~cm} \times 19 \mathrm{~cm}$, with six flasks connectors. Chambers were placed on top of a closed cell foam frame that allowed an air-tight seal between the rigid chamber and the uneven surface of the tree stem. We used nylon straps to compress the foam, while the sealant was applied between the foam and stem for ensuring the seal (Hilman and Angert, 2016). Sealants were silicone-based vacuum grease (Silicaid ${ }^{\circledR} 1010$ manufactured by Aidchim Ltd., Raanana, Israel) or hot glue applied by a hot-glue gun. ${ }^{\mathrm{c}}$ The chambers are described in Muhr et al. (2013) and Carbone et al. (2013). Briefly, the chambers were made from an opaque plastic polypropylene pipe T fitting with fittings for sampling flasks. Sealants were caulking (Nautiflex; OASE GmbH, Oerel-Barchel, Germany) or hot glue applied by a hot-glue gun. ${ }^{\mathrm{d}}$ Chambers were built from a $15 \mathrm{~cm}$ long piece of polypropylene (PP) tubing ( $6.5 \mathrm{~cm}$ OD) that was welded shut on both sides with a PP disc $(6.7 \mathrm{~cm}$ diameter). By cutting off a segment (height $2 \mathrm{~cm})$ the tube was turned into an incubation chamber. Opposite the chamber opening, three fittings (Sprint ESKV 20, Wiska, Germany) were installed and sealed around the edges with liquid rubber (Dichtfix, Bindulin, Fürth, Germany). For sampling, chambers were attached to the trees with four lashing straps. To achieve a gas-tight seal, a frame ( $25 \mathrm{~mm}$ thick) made from closed-porous cellular rubber (EPDM quality, REIFF Technische Produkte GmbH, Reutlingen, Germany) was placed between the chamber and the stem.
} 


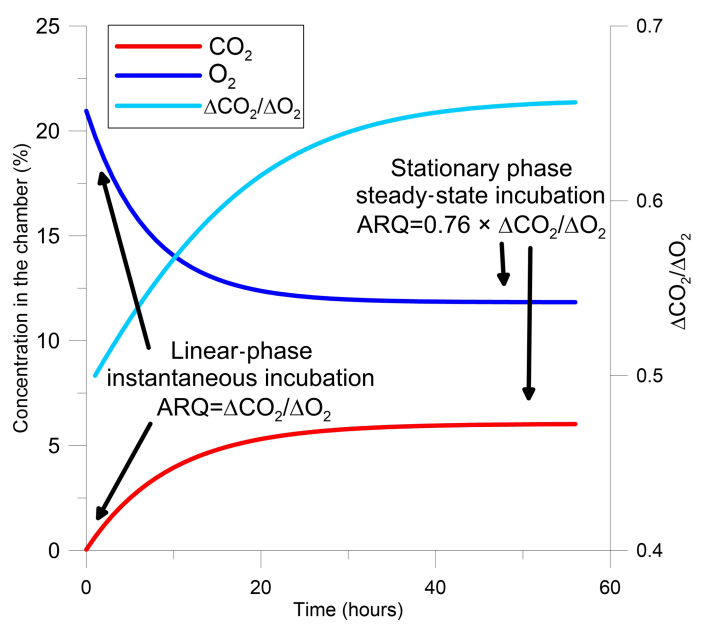

Figure 1. Modeled changes in a tree stem chamber of the concentrations of $\mathrm{CO}_{2}, \mathrm{O}_{2}$, and the ratio between $\Delta \mathrm{CO}_{2}$ and $\Delta \mathrm{O}_{2}$, which are the changes in the gas concentrations from their initial values and are also the difference in concentrations between the chamber and the atmosphere. The gas dynamics are based on a one-box model with arbitrary fluxes and ARQ (ratio of $\mathrm{CO}_{2}$ efflux $/ \mathrm{O}_{2}$ influx for tree stems) equal to 0.5 . The two time frames in which ARQ can be measured from the ratio $\Delta \mathrm{CO}_{2} / \Delta \mathrm{O}_{2}$ are indicated in the figure.

where $\Delta \mathrm{CO}_{2}$ and $\Delta \mathrm{O}_{2}$ are the changes in $\left[\mathrm{CO}_{2}\right]$ and $\left[\mathrm{O}_{2}\right]$ during the initial period after the chamber was sealed, and for discrete samples can also be determined from the difference in concentrations between the chamber air sampled at a specific time and the initial atmosphere. Instantaneous fluxes of $\mathrm{CO}_{2}$ and $\mathrm{O}_{2}$ reported here are obtained either by monitoring concentration change during the first hour following chamber closure with sensors directly in the field or by sampling headspace air with glass flasks within $30 \mathrm{~min}$ to a few hours of closing the chamber. The flasks were transported to the laboratory for measurement of $\mathrm{CO}_{2}$ and $\mathrm{O}_{2}$.

After the first hours, the initially linear rates of change in headspace gas concentration with time decline and concentrations eventually remain constant (Figs. 1, S1). In this phase the gases in the chamber and the outer part of the stem, where most of the metabolism takes place, are assumed to be in equilibrium. This steady state occurs when the rates of addition of $\mathrm{CO}_{2}$ and loss of $\mathrm{O}_{2}$ from the stem to the chamber headspace are balanced by diffusive (assuming no strong wind) exchange of headspace air with outside air through porous portions of the outer stem. For steady-state samples, the chamber is sealed to the surface of the stem and left for a period longer than $24 \mathrm{~h}$, after which the headspace air is sampled using glass flasks. The $\mathrm{CO}_{2}$ and $\mathrm{O}_{2}$ concentrations must be corrected for differences in diffusivity between $\mathrm{CO}_{2}$ and $\mathrm{O}_{2}$, as detailed in Angert and Sherer (2011), Angert et al. (2012), and Hilman and Angert (2016) in order to estimate the ratio of the gas fluxes from the concentrations in the static chamber:
$\mathrm{ARQ}=\frac{\mathrm{gCO}_{2} \times \Delta \mathrm{CO}_{2}}{\mathrm{gO}_{2} \times \Delta \mathrm{O}_{2}}$,

where $\mathrm{gCO}_{2}$ and $\mathrm{gO}_{2}$ are the $\mathrm{CO}_{2}$ and $\mathrm{O}_{2}$ conductance values in the outer layer of the stem between the chamber and the atmosphere. The structure of the path along which diffusion occurs is the same for $\mathrm{CO}_{2}$ and $\mathrm{O}_{2}$ and hence the conductance ratio $\mathrm{gCO}_{2} / \mathrm{gO}_{2}$ depends solely on the ratio of diffusivities of the gases in air, which is 0.76 (Massman, 1998). As a result, at steady state

$\mathrm{ARQ}=0.76 \times \frac{\Delta \mathrm{CO}_{2}}{\Delta \mathrm{O}_{2}}$.

Assuming constant $\mathrm{CO}_{2} / \mathrm{O}_{2}$ fluxes over time, samples taken either by instantaneous or steady-state methods will yield the same ARQ values. Indeed, Hilman and Angert (2016) demonstrated excellent agreement for direct comparisons of the instantaneous and steady-state measurement methods, and the results are further compared here.

\subsubsection{Stem chambers and gas measurements}

All data reported here were collected by using chambers attached to the stem surface to create a gas-tight incubation headspace. Chamber designs and sampling details differed between sites (see Sect. 2.2 and Table 1), but generally all chambers were equipped with sampling ports for attaching glass flasks equipped with O-ring valves (LouwersHanique, Hapert, the Netherlands). Outside incubations, permanently installed chambers were protected against insect infestation using screens. Incubations were always started at ambient concentration, and flasks were allowed to equilibrate with the headspace by opening the flasks' valves during incubation. Incubation time varied from between $30 \mathrm{~min}$ to a few hours for instantaneous ARQ samples to more than $24 \mathrm{~h}$ for steady-state samples. At the end of the incubation period, the flask valve was closed and the gas sample was shipped to the laboratory for analysis. Each reported ARQ measurement is the average of duplicate flasks taken from the stem chamber, and the error is the standard deviation.

The $\mathrm{CO}_{2} / \mathrm{O}_{2}$ ratios in the flasks were analyzed in the laboratory at the Hebrew University of Jerusalem in a closed system (the Hampadah; Hilman and Angert, 2016). Two analyzers are included in the Hampadah system; an infrared gas analyzer (IRGA) for $\mathrm{CO}_{2}$ measurement (LI-840A LI-COR; Lincoln, NE, USA) and a fuel-cell-based analyzer (FC-10; Sable Systems International, Las Vegas, NV, USA) for measuring $\mathrm{O}_{2}$. The principle of operation of the Hampadah is measurement of the change in $\mathrm{CO}_{2}$ and $\mathrm{O}_{2}$ concentrations in the system's air after the addition of the air from a given sample flask of known volume and calculation of the concentration in the flask that would yield that overall concentration change (Hilman and Angert, 2016). 


\subsubsection{Continuous ARQ measurements}

Sensitive detection of small changes in $\mathrm{O}_{2}$ is difficult in the field, which is why we used the flask samples and long chamber closure times (steady state) in most field sites. However, to measure diurnal changes in stem ARQ values of Malus domestica, we were able to make continuous measurements with a small IRGA $\mathrm{CO}_{2}$ sensor (COZIR Wide Range $0 \%-20 \% \mathrm{CO}_{2}$ Sensor, CO2Meter, Inc., Ormond Beach FL, USA) and a quenching-based optode (Fibox 3, PreSens Precision Sensing, Regensburg, Germany) for $\mathrm{O}_{2}$ measurement (Hilman and Angert, 2016). The sensors' reading was extracted every $30 \mathrm{~s}$. A temperature sensor was placed next to the optode sensor for temperature and water vapor corrections. The inlet of a small diaphragm pump (KNF micropump) and a non-return valve (SMC AKH $12 \mathrm{~mm}, \mathrm{RS}, \mathrm{UK}$ ) were connected to the chamber headspace and used to automatically vent the chamber headspace every $4 \mathrm{~h}$. The $\mathrm{CO}_{2}$ efflux and the $\mathrm{O}_{2}$ influx were calculated using a linear fit over $\sim 120$ gas concentration measurements during the first hour of incubation, the chamber volume, and the stem surface area under the chamber. We used the data from this experiment to examine the sensitivity of ARQ to temperature, which affects the gas solubility constants. The strongest effects are expected during the night, when daytime influences on stem fluxes associated with sap flow and low turgor pressure (Salomón et al., 2018) are minimized.

\subsection{Study sites and experimental design}

For addressing the variation in stem ARQ values across a range of tree species and environments, our study included trees located in tropical forests (Panama and Brazil), in temperate forests (Bartlett and Harvard, USA), and in a Mediterranean savanna (Spain) and a Mediterranean shrubland (Carmel Ridge, Israel). We also included five trees located on the Hebrew University campus in Jerusalem (Israel) and in the adjacent Jerusalem Botanical Gardens. The trees in Panama were part of a fertilization and litter manipulation project (Wright et al., 2011; Sayer and Tanner, 2010). No treatment effects were found (Fig. S2, this topic is not in the scope of this paper). Details about the sites, tree species, stem chambers, stem dimensions, and experiments conducted in each of the sites are presented in Table 1 and Fig. 3. The list below summarizes what data were available from the different sites and what questions in particular we addressed with these data (the numbering of the experiments matches Table 1):

A. Seasonal and/or phenological measurements of stem ARQ were performed in Jerusalem, US, and Brazil sites. In Jerusalem, five individual trees from five different species (first five species in Table 1) were measured. The phenological state of deciduous trees (all except Quercus calliprinos) was separated into four classes (Fig. 4). In the US sites, trees measured at the northern site (Bartlett Experimental Forest) had fall color development, while leaves at Harvard Forest (southern site) were still green. After analysis of flasks, we excluded results from three trees because of suspected air leakage from the chamber $\left(\mathrm{O}_{2}>20 \%\right.$ after 6 days of stem incubation). In Brazil, six trees were measured. After analysis we excluded results from 4 out of 12 instantaneous measurements because of a weak signal $\left(\mathrm{O}_{2}>20.7 \%\right.$ and $\mathrm{SD}>0.1$ after $3 \mathrm{~h}$ of incubation).

For our second objective, to explore the potential for low ARQ values to reflect dissolution and transport of $\mathrm{CO}_{2}$ in the xylem sap, we measured instantaneous ARQ at varying sap flow velocities and at different times of a day. Transport of $\mathrm{CO}_{2}$ was previously reported to be correlated with sap flow (McGuire and Teskey, 2004; Bowman et al., 2005; McGuire et al., 2007). Thus, anti-correlation of ARQ with sap flux, expressed via maximal ARQ values during the night when transport is at a minimum, would provide evidence that low ARQ can be explained by export of locally respired $\mathrm{CO}_{2}$ (as DIC) out of the stem region being measured (experiments $\mathrm{B}$, $\mathrm{C}$, and $\mathrm{E}$, below). If transport of dissolved $\mathrm{CO}_{2}$ is the main driver of low ARQ values, we would also expect that (D) higher ARQ values will be observed at higher temperatures (due to differential temperature dependences of $\mathrm{CO}_{2} / \mathrm{O}_{2}$ solubility coefficients), (F) ARQ values will increase with stem height due to DIC accumulation and stem tapering that induce stronger $\mathrm{CO}_{2}$ diffusive loss, (F) ARQ values will decrease with depth in the stem (due to the greater proximity to the water conducting vessel elements), and (G) ARQ values in incubated stem cores will be higher than measured values at the stem surface (due to the detachment from the transport system).We performed a number of experiments to test each of these predictions (additional details in Table 1):

B. ARQ (instantaneous) was measured simultaneously with sap flux density measurements in nine Quercus ilex trees with similar diameter $(0.35$ to $0.49 \mathrm{~m}$ at breast height) at the site in Spain.

C. ARQ (instantaneous) was measured during daytime, at predawn when the transpiration stream should reach its minimum, and again during the next day. We conducted two day-night campaigns on the trees at the site in Jerusalem. Additionally, during 4 days, ARQ (continuous) values were measured every $4 \mathrm{~h}$ from the $M$. domestica tree in Jerusalem.

D. Nighttime results of the continuous ARQ measurements on the $M$. domestica enabled us to examine the relationship between temperature and ARQ. During the night, when sap flux is minimal, the temperature effect on the gases' solubility should have its maximum effect on ARQ values.

E. ARQ (steady state) was measured over spring, summer, and winter for Quercus calliprinos trees on the Carmel 
Ridge site, simultaneously with predawn shoot water potential $\left(\Psi_{\mathrm{pd}}\right) . \Psi_{\mathrm{pd}}$ is a measure for available soil water and therefore is also a rough proxy for seasonal differences in transpiration rates (Aranda et al., 2005; Bucci et al., 2005).

F. ARQ was measured at different heights on the same tree stems, while simultaneously ARQ was determined from air sampled inside the stem. During the seasonal measurements in Jerusalem, ARQ (steady state) was measured at the stem base of the Q. calliprinos and the Platanus occidentalis trees as well as at breast height. In Brazil, we measured ARQ (instantaneous) from stem chambers and in-stem probes to sample in-stem gases from the tree base up to $11 \mathrm{~m}$ above the ground on a single Scleronema micranthum tree on two separate days.

G. ARQ (steady state) measured from stem chambers was compared with ARQ measurements through incubation of stem cores. Measurement of stem tissues should provide better estimation for the stem outer layers' RQ by excluding dissolution and advection in the xylem stream. Incubations were performed on cores taken from four species in four different sites (Table 1). In Jerusalem, we compared repeated stem incubation ARQ with that of leaf incubation.

\subsection{Sap flux density}

Sap flux density was monitored in nine trees at the site in Spain using heat ratio method (HRM) sensors (SFM1 Sap Flow Meter, ICT International). A description of the installation and measurement is presented in Methods S1. The detailed procedures for sap flux corrections and calculations are described in Perez-Priego et al. (2017). We tested whether the daily maximum sap flux density (i.e., average of measurements between 10:00 and 17:00 local time during the day of the ARQ measurement), which correlated with $\mathrm{CO}_{2}$ dissolution fluxes (Bowman et al., 2005), could explain variability in ARQ (instantaneous).

\subsection{Shoot water potential}

Predawn shoot water potential $\left(\Psi_{\mathrm{pd}}\right)$ on Carmel Ridge was measured using a pressure chamber (PMS Instrument Company, Corvallis, Oregon, USA). At each sampling time, we sampled 2-3 terminal twigs containing 5-10 leaves from each tree. The samples were wrapped in plastic, placed on ice, and measured within an hour of sampling using the pressure chamber technique (Scholander et al., 1965).

\subsection{In-stem measurements}

For sampling gas from inside the stem, stainless-steel tubes ( $1.3 \mathrm{~cm}$ diameter) were installed 4,8 , and $12 \mathrm{~cm}$ deep into the stem, in various stem heights on the same tree in Brazil where the vertical ARQ transects were measured. Installation procedure was according to Muhr et al. (2013) and tubes were sealed between sampling dates. Using rubber tubing we connected the sampling flasks to the tubes for incubation of 4 days. The flasks were then analyzed for $\mathrm{CO}_{2}$ and $\mathrm{O}_{2}$ in the Hampadah. Assuming steady state, ARQ was calculated using Eq. (3) (Angert et al., 2012).

\subsection{Measuring ARQ of incubated tissues}

Stem cores were extracted immediately after the chamber incubation experiment in Panama, Spain, and Jerusalem using a $1.2 \mathrm{~cm}$ diameter cork borer. The outer bark and green tissues, as well as sapwood sieves (with paler color than the phloem tissues), were removed from the cores. The cores were cut into longitudinal halves, wrapped with moist gauze cloth to avoid desiccation, and placed in an air-tight incubation system to which glass flasks (two or three) were connected by Swagelok Ultra-Torr fittings (Swagelok, Solon, $\mathrm{OH}$, USA, Fig. S4). At the end of the incubation period, the flasks were closed and analyzed in the Hampadah. Since the incubations took place in a closed system (no diffusive exchange with outside air), the changes with time in $\left[\mathrm{CO}_{2}\right]$ and $\left[\mathrm{O}_{2}\right]$ are assumed to be linear, and ARQ can be calculated using Eq. (1).

In Panama and Spain the incubations were started immediately upon core extraction, at ambient temperature, and lasted 8 and $3 \mathrm{~h}$, respectively. In Jerusalem the cores were kept on moist gauze cloth for $2 \mathrm{~h}$ before being sealed in the incubation system and kept at $25^{\circ} \mathrm{C}$ in an environmental chamber. Repeated incubations were performed in series, with the incubation systems flushed in between with ambient air. Simultaneously, from each tree, four leaves from an understory branch were cut and inserted into the same incubation systems, for the same incubation durations. The $\mathrm{O}_{2}$ uptake rate $\left(\mathrm{nmol} \mathrm{O}_{2} \mathrm{~g} \mathrm{FW}^{-1} \mathrm{~s}^{-1}\right)$ was calculated as follows (adopted from Pruyn et al., 2002):

$\mathrm{O}_{2}$ uptake rate $=\frac{\Delta \mathrm{O}_{2}}{100} \times \frac{V_{\mathrm{H}}}{T \times M_{\mathrm{FW}} \times V_{\mathrm{m}}} \times 10^{9}$,

where $\Delta \mathrm{O}_{2}$ is the decrease in $\left[\mathrm{O}_{2}\right]$ during the incubation, $V_{\mathrm{H}}$ is the volume of headspace $(\mathrm{mL}), T$ is the incubation period (s), $M_{\mathrm{FW}}$ is the fresh weight $(\mathrm{g}), V_{\mathrm{m}}$ is the molar volume, and $10^{9}$ converts units to nmol. We dried the samples in an oven at $60^{\circ} \mathrm{C}$ for 2 days for the dry weight.

In Brazil, stem cores were extracted by using a $5.15 \mathrm{~mm}$ diameter increment corer. After bark was removed the cores were cut to a length of $6 \mathrm{~cm}$ each and then allowed to equilibrate with the atmosphere for $6-8 \mathrm{~h}$, while continually being kept moist. After equilibration, each core was transferred to an incubation chamber equipped with flasks. Prior to starting the incubation, a few milliliters of water were added to keep the core tissue moist. In this case, incubations were left at room temperature $\left(\sim 25^{\circ} \mathrm{C}\right)$ for $24 \mathrm{~h}$ before flasks were closed and removed. 


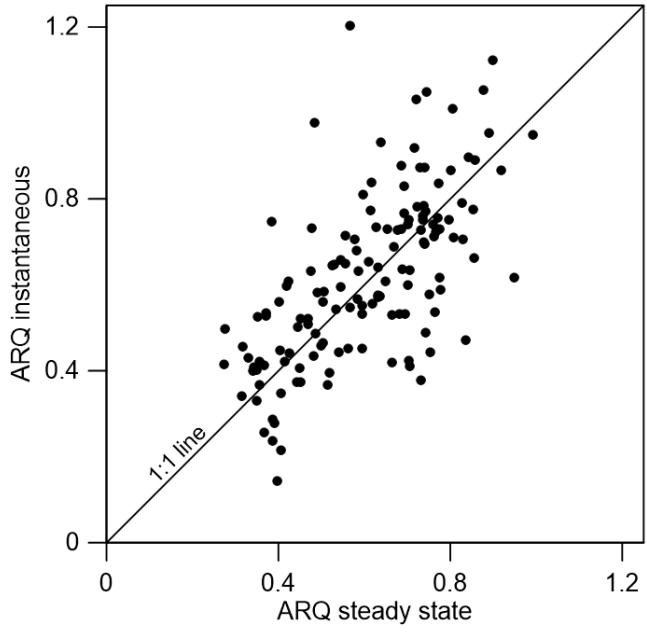

Figure 2. Scatter plot of instantaneous ARQ (ratio of $\mathrm{CO}_{2}$ efflux $/ \mathrm{O}_{2}$ influx for tree stems) measured in stem chambers after incubation of $30 \mathrm{~min}$ to a few hours and steady-state ARQ measured in the same experiment with typically 2 days of incubation $(n=139)$.

\subsection{Statistical analysis}

All statistical analysis was done using JMP (JMP ${ }^{\circledR}$, JMP Pro 13, SAS Institute Inc., Cary, NC, USA). Repeated-measures analysis of variance (ANOVA) was used to evaluate how the interaction of tissue (stem core and leaves) with ARQ and $\mathrm{O}_{2}$ uptake varies with time in the repeated incubations of the tissues from the trees in Jerusalem. Mauchly's test indicated violation of sphericity in the ARQ response in the repeated incubations experiment $\left(\chi^{2}=18.132, P=0.021\right)$; therefore, the Greenhouse-Geisser adjusted $F$ test was chosen. One-way ANOVA followed by Tukey-Kramer HSD (honestly significant difference) was used to perform comparisons among time points in every tissue. A Student's $t$ test was used for comparisons between stem cores and leaves at each time point.

\section{Results}

The ARQ values estimated from instantaneous and steadystate measurements were in good agreement over a large range of ARQ values (Fig. 2). The mean difference between the two assessments is 0.02 , and RMSD is 0.15 . The average ARQ (steady state) value across all species and sites, including results from Angert et al. (2012), was $0.59(n=229)$ and the average ARQ of species in the different sites ranged between 0.39 and 0.78 (Fig. 3). For individual measurements, a minimum ARQ value of 0.27 was recorded for $Q$. ilex in Spain and for Tetragastris panamensis in Panama. The highest value was 0.99 for M. domestica and Populus deltoids in Jerusalem.
Phenology or seasonality had some effect on ARQ. In Jerusalem, the ARQ of Q. calliprinos and Pistacia atlantica was lower during spring and higher in fall and winter (Fig. 4). In Brazil, ARQ varied between $0.41 \pm 0.15$ in the wet season (March) and $0.82 \pm 0.12$ in the dry season (October, Fig. S3). The average ARQ of the Acer rubrum trees at Harvard Forest, where all leaves were green, was significantly higher than the average ARQ of the trees at Bartlett Experimental Forest, where the leaves had autumn color development (0.69 vs. $0.57, P<0.05$ in a Student's $t$ test).

\subsection{ARQ values under varying xylem stream flow and temperature}

ARQ (instantaneous) values of nine $Q$. ilex trees in Spain were invariable (mean $\pm \mathrm{SD}$ of $0.42 \pm 0.04$ ) in comparison with the larger variation in maximum daily sap flux density among these trees $\left(0.15 \pm 0.05 \mathrm{~m}^{3} \mathrm{H}_{2} \mathrm{O} \mathrm{m}^{-2} \mathrm{~h}^{-1}\right)$, and no correlation was found between the ARQ and sap flux density $\left(r^{2}=0, P=0.9891\right)$.

Mean $\mathrm{ARQ} \pm \mathrm{SD}$ values (steady state) of the trees at the Carmel Ridge site were $0.62 \pm 0.06,0.68 \pm 0.07$, and $0.69 \pm$ 0.08 for spring, summer, and winter, respectively. Repeatedmeasures analysis of variance found no significant difference between seasons $\left(F_{2,2}=2.52, P=0.28\right)$, while $\Psi_{\mathrm{pd}}$ varied significantly with seasons $\left(F_{2,2}=207.85, P=0.0048\right)$. During summer, $\Psi_{\mathrm{pd}}$ was $-2.65 \mathrm{MPa}$, much lower than the spring and winter values $(-0.64$ and $-0.86 \mathrm{MPa}$, respectively).

In the Jerusalem day-night campaigns, ARQ (instantaneous) values ranged between 0.52 and 1.05 , across all trees, seasons, and sampling times (Fig. 5). Predawn ARQ values exceeding than daylight values (by amounts larger than the differences between duplicates) were observed during the summer in M. domestica and in the upper chamber on Q. calliprinos. No significant diurnal effect was found in repeatedmeasures analysis of variance of the breast height chambers, neither when results of all the trees were grouped by season nor when results were grouped by stem chamber. In continuous measurements of $M$. domestica, with ARQ values obtained every $4 \mathrm{~h}$, ARQ during the night $(0.70 ; n=12)$ was not significantly $(P>0.76$ in a Student's $t$ test) greater than in the day $(0.71 ; n=11 ;$ Fig. 6$)$. The variations among the nighttime values were best explained using temperatures measured $235 \mathrm{~min}$ before the ARQ measurement $\left(r^{2}=0.84\right.$, $P=0.0001$, ARQ $=0.01 \times$ temperature $\left.\left({ }^{\circ} \mathrm{C}\right)+0.54\right)$. With the same time lag, the coefficient of determination for the daytime values is $r^{2}=0.44(P=0.0266)$.

\subsection{Stem surface and in-stem ARQ vertical transects}

In $Q$. calliprinos, measured over 3 years in Jerusalem, ARQ did not differ significantly $(P>0.33$ in a Student's $t$ test) between breast height and stem base (ARQ of 0.56 vs. 0.59 , respectively, $n=14$, Fig. 4). For $P$. occidentalis measured for 


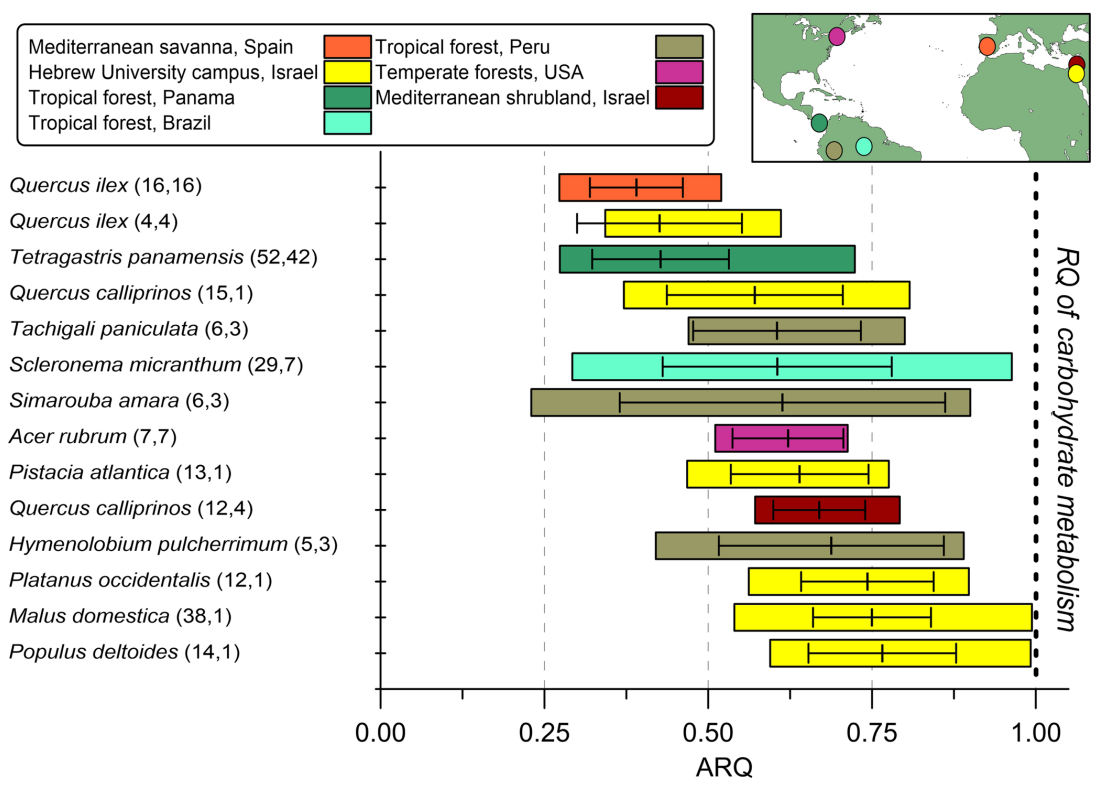

Figure 3. Summary of steady-state ARQ (ratio of $\mathrm{CO}_{2}$ efflux $/ \mathrm{O}_{2}$ influx for tree stems) for 12 species ( $n$ measurements, $n$ individuals). Gases were sampled from chambers at breast height $(\sim 1.3 \mathrm{~m}$ above soil surface), except for the $Q$. calliprinos in the Mediterranean shrubland, in which chambers were placed near the stem base due to branching stems. Vertical lines are mean values, error bars represent one standard deviation, and colored bars represent the range of measured ARQ values. The Peru data are from Angert et al. (2012). The horizontal bars were ordered according to increasing mean ARQ.

the same period the ARQ measured at breast height was significantly higher than ARQ measured at the stem base $(0.74$ vs. 0.64 , respectively, $n=12, P=0.003$ in a Student's $t$ test, Fig. 4). For a single S. micranthum tree in Brazil, ARQ values measured at heights of 6.5 and $11 \mathrm{~m}$ above the ground were similar to ARQ measured at breast height (Fig. 7), but also show differences with the stem base. In this tree, ARQ measured in March $(0.46 \pm 0.11$; wet season) was lower than in October $(0.89 \pm 0.16$; dry season). The in-stem ARQ values ranged between 0.25 and 0.56 , with average \pm SD of $0.46 \pm 0.07$ in both seasons and at all stem positions and depths. The in-stem ARQ, as well as $\left[\mathrm{CO}_{2}\right]$ values, had no clear vertical trend (Figs. 7; S5).

\subsection{Tissue incubations}

The average ARQ values of the stem core incubations were similar to the stem chamber ARQ for the four sites and trees where these comparisons were made (Fig. 8). When incubations were repeated over time for $Q$. ilex stem cores and leaves, significant effects of time, tissue (leaves, stem cores), and their interactions (time $\times$ tissue) on ARQ and $\mathrm{O}_{2}$ uptake rates were observed. ARQ of the stem cores increased from $0.44 \pm 0.08$ (mean $\pm \mathrm{SD}, n=4)$ after $3 \mathrm{~h}$ to $0.94 \pm 0.03$ at the end of the experiment ( $32 \mathrm{~h}$; Fig. 9). The ARQ of incubated leaves of the same trees showed higher initial ARQ of $0.80 \pm 0.02$, with an increase over time to $0.92 \pm 0.02$.

\section{Discussion}

\subsection{ARQ is lower than 1.0 for a wide range of tree species}

The ARQ measured in stem chambers installed on 85 individual trees of nine species including tropical, temperate, and Mediterranean forest trees was considerably and almost universally lower than 1.0. ARQ values as low as 0.7 could indicate that lipids were used exclusively as substrates for respiration, but current understanding suggests this scenario is implausible. However, this understanding relies on low and constant lipid concentrations over seasonal sampling (Hoch et al., 2003); daily changes in lipid concentrations and RQ were measured in response to shading and drought treatments, indicating this substrate might be more important than commonly thought (Fischer et al., 2015; Hanf et al., 2015). Nevertheless, many of the measured ARQ values were below 0.7 , so substrate use alone cannot explain them. Additionally, as ARQ values above 1.0 are expected when lipids are produced (De Vries et al., 1974), ARQ $<1.0$ resulting from lipid metabolism must be mirrored with ARQ $>1.0$ at a different time (assuming the lipids are produced locally). However, ARQ almost never exceeded 1.0. The results demonstrate that $\mathrm{O}_{2}$ influx to the stems usually exceeded the $\mathrm{CO}_{2}$ efflux, regardless of tree species, site, season, and time of day. Assuming $\mathrm{O}_{2}$ uptake provides a measure of in situ respiration (due to the low solubility of $\mathrm{O}_{2}$ ) and carbohydrates are the main substrate, values of ARQ averaging 0.59 indicate that 


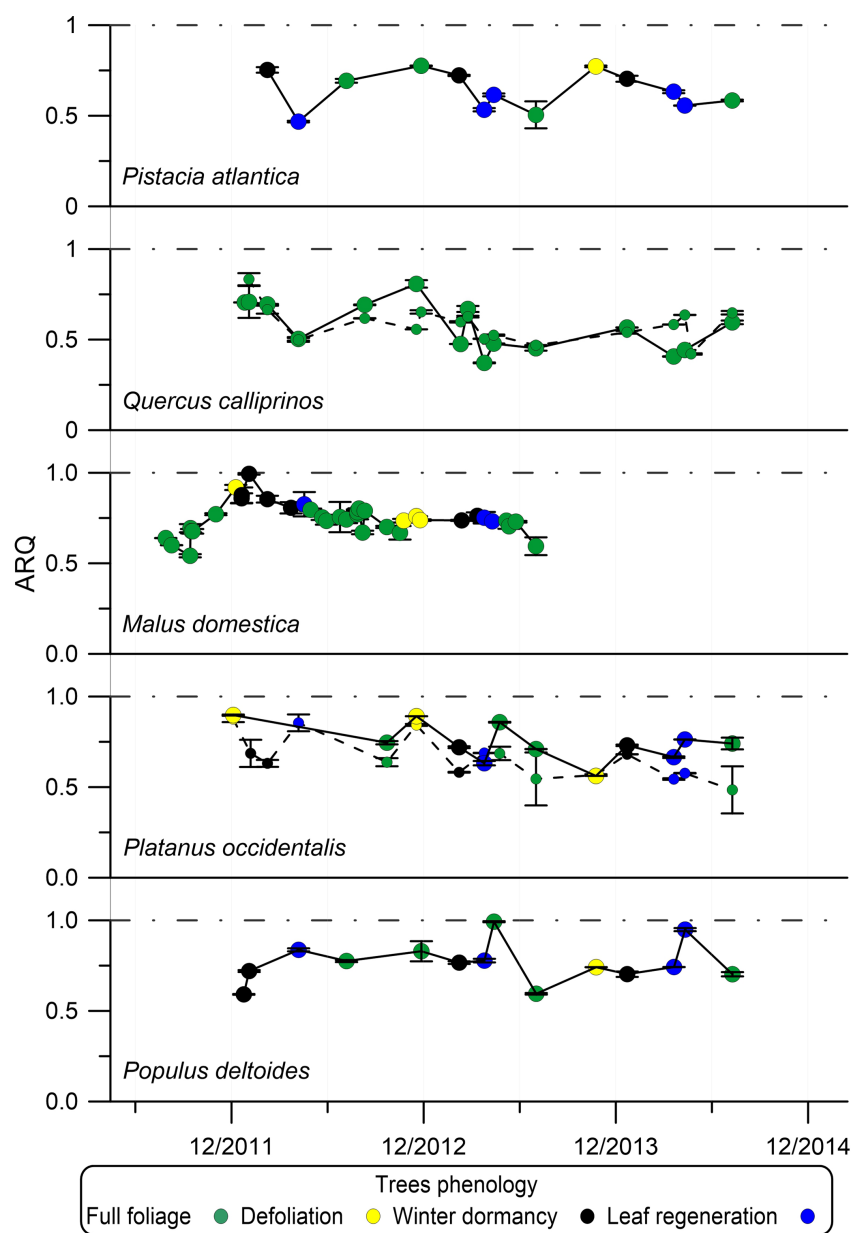

Figure 4. Seasonal dynamics of steady-state ARQ (ratio of $\mathrm{CO}_{2}$ efflux $/ \mathrm{O}_{2}$ influx for tree stems) of five individual trees from five different species. Phenology stage index determined according to "defoliation" - from beginning of autumn color development to the end of the fall, "winter dormancy" - when the tree was bare from leaves, and "leaf regeneration" - from bud burst to early leaf development stage. The $Q$. calliprinos is evergreen. Markers are mean values and error bars are SD of duplicate samples from the same stem chamber. Markers connected with solid lines represent measurements with chambers at breast height $(\sim 1.3 \mathrm{~m}$ above soil surface). Smaller markers connected with dashed lines represent measurements with chambers positioned at the stem base. The trees grew on the Hebrew University campus in Jerusalem, Israel.

on average $41 \%$ of the $\mathrm{CO}_{2}$ produced by respiration was not locally emitted to the atmosphere, but apparently retained in the stem.

For sites where we have time series data for the same individuals, considerable variations in ARQ values were observed over 2 years in Brazil (Fig. S3) and over 3 years in Jerusalem (Fig. 4). A decrease in ARQ values was often observed during entrance to dormancy for the deciduous trees in Jerusalem, as well as an apparent minimum in ARQ for $P$. atlantica and $Q$. calliprinos in spring (Fig. 4). The au-
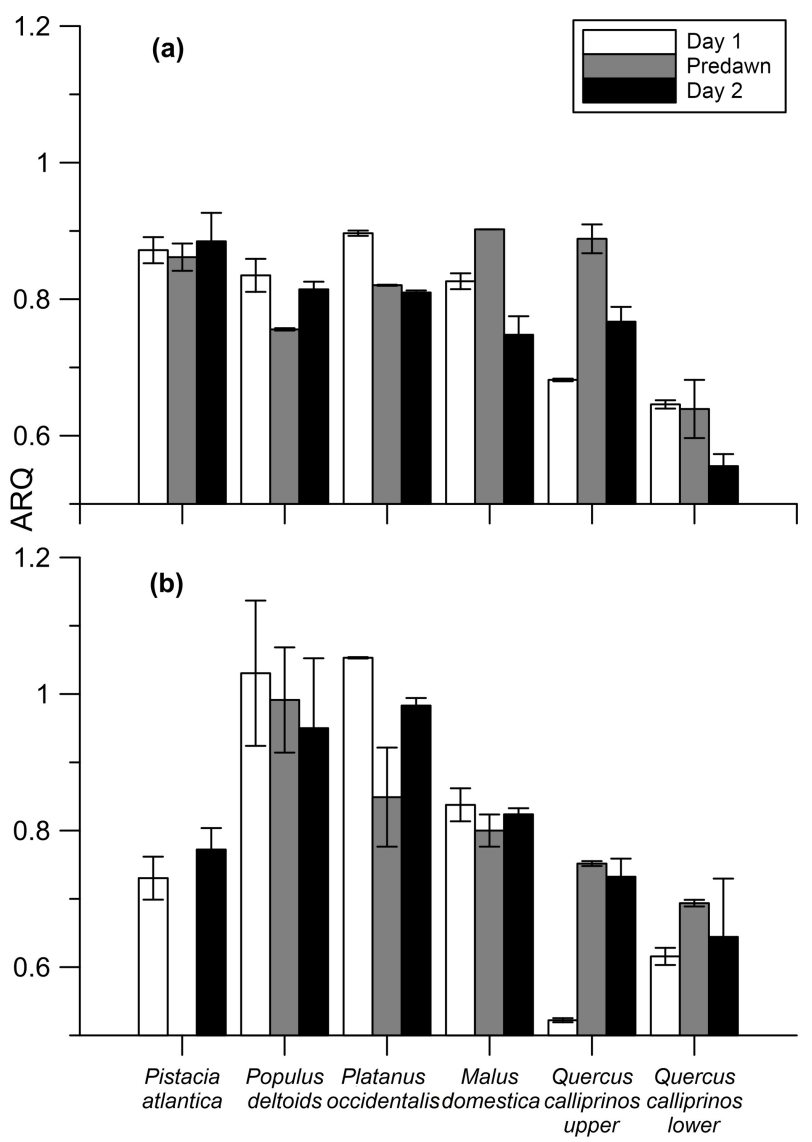

Figure 5. Instantaneous ARQ (ratio $\mathrm{CO}_{2}$ efflux/ $\mathrm{O}_{2}$ influx for tree stems \pm SD of duplicates) values measured over a day-night-day transition during July 2012 (a) and April 2013 (b) from different trees growing on the Hebrew University campus in Jerusalem, Israel. Quercus calliprinos was measured at two different heights on the stem. The first sampling was taken during daylight (day 1), next sampling before dawn (predawn), and last sampling during daylight of the successive day (day 2).

tumn decrease seems to be in agreement with the finding of significantly lower ARQ for Bartlett Experimental Forest, where leaves were beginning to senesce, compared to the more southerly Harvard Forest, where leaves were still green.

The possibility of measurement artifacts as the source for the low ARQ values seems unlikely, as Hilman and Angert (2016) previously demonstrated the validity of the measurement methods and the box-model approach. Further support comes from the small mean difference $(0.02)$ between the instantaneous and steady-state ARQ measured for the same tree, which reflects overall agreement between the measures. The considerable scatter around perfect agreement (Fig. 2), expressed also in RMSD of 0.15 , could be taken as an indication that the measurement methods differ significantly. However, since the model assumes constant ARQ with time, and temporal changes in ARQ are obviously 


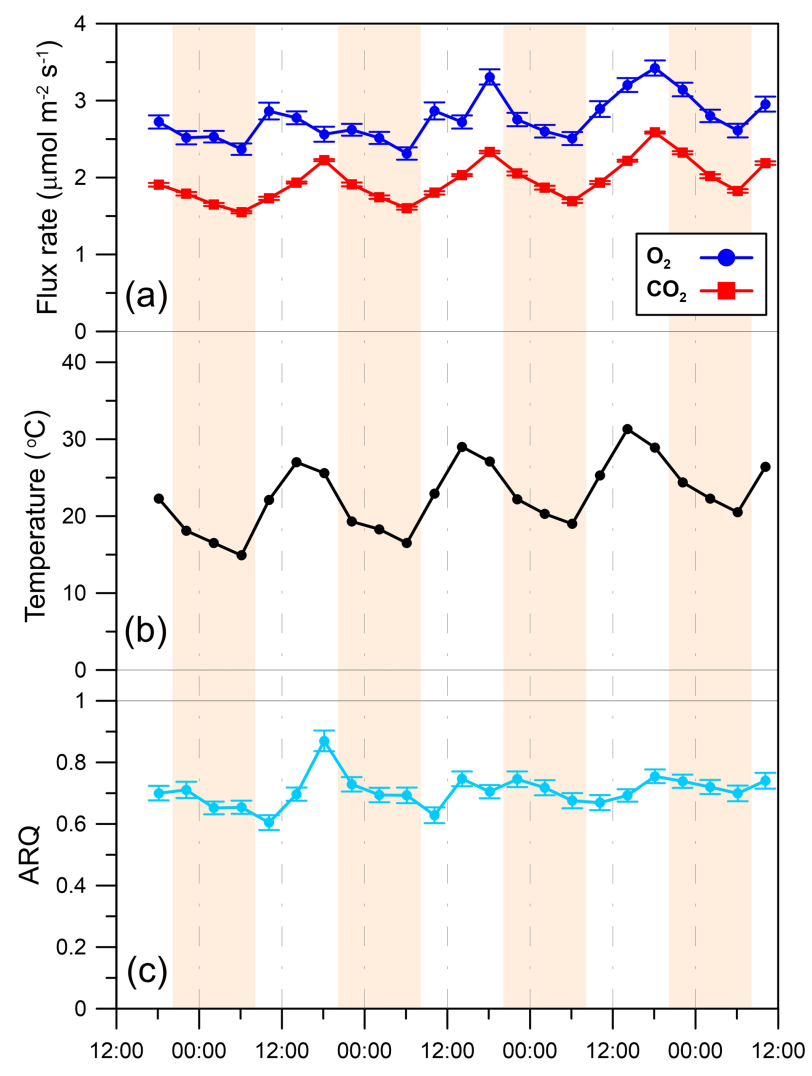

Figure 6. Diurnal patterns of (a) $\mathrm{O}_{2}$ influx to the stem and $\mathrm{CO}_{2}$ efflux from the stem, (b) chamber temperature, and (c) instantaneous ARQ (ratio $\mathrm{CO}_{2}$ efflux $/ \mathrm{O}_{2}$ influx for tree stems). Shaded areas indicate night periods. Error bars are $95 \%$ confidence bounds. All data were obtained from a single $M$. domestica tree during 24 28 April 2013 on the Hebrew University campus in Jerusalem, Israel.

present as shown in Figs. 5 and 6, the scatter could also be attributed to temporal differences in the time integrated by the two types of measurement: the instantaneous sampling was typically conducted a few days before the steady-state sampling on the same tree. Additionally, the precision for instantaneous ARQ was lower than for steady-state values, due to smaller changes in $\mathrm{O}_{2}$ over the shorter time periods. This may also contribute to the scatter in Fig. 2 (Hilman and Angert, 2016). We also found strong similarities between ARQ measured on intact stems using chambers and ARQ determined by incubating stem cores (Fig. 8). This provides another, indirect, confirmation that the low ARQ values obtained with the stem chamber measurement approaches are measuring something that is occurring in the stem tissues.

\subsection{Dissolution and transport of respired $\mathrm{CO}_{2}$ in xylem stream cannot explain the low ARQ values}

Given the low solubility of $\mathrm{O}_{2}$, stem flux ARQ values $<1.0$ (or potentially $<0.7$ for "fat trees") are the result of respired $\mathrm{CO}_{2}$ either being exported from the site of respiration be-

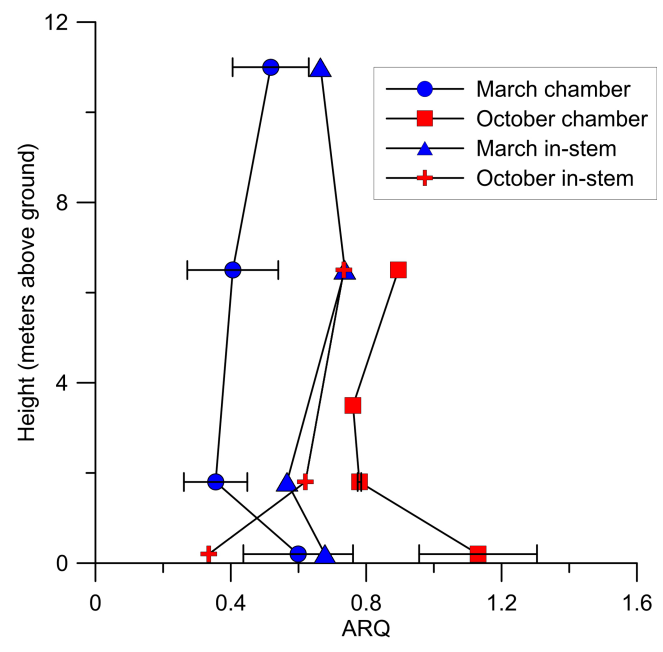

Figure 7. Instantaneous ARQ (ratio of $\mathrm{CO}_{2}$ efflux $/ \mathrm{O}_{2}$ influx for tree stems) measured from stem chambers installed at different heights above the ground on a $S$. micranthum tree in Brazil. At the same heights ARQ was measured from $4 \mathrm{~cm}$ in-stem probes. The measurements were conducted during 30 March and 18 October 2012. Error bars represents SD of duplicate samples from the same stem chamber.

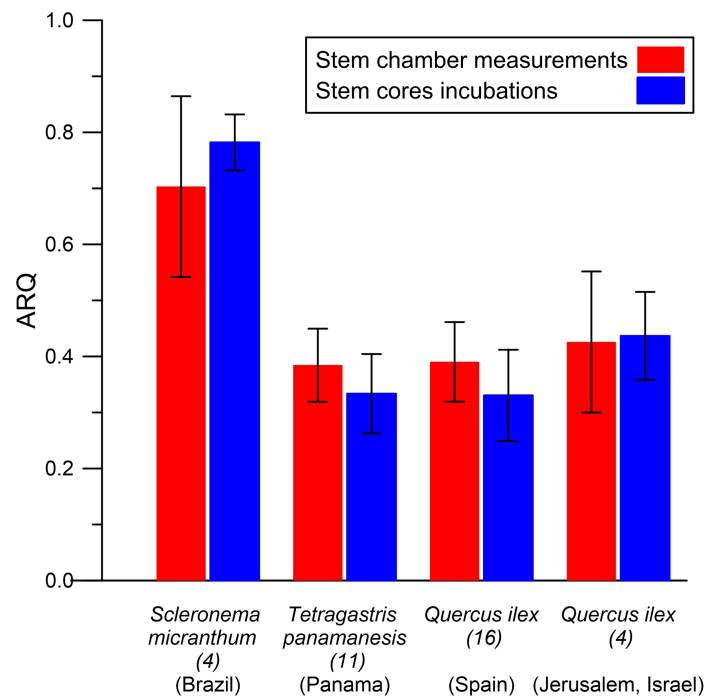

Figure 8. Comparisons of stem chamber steady-state ARQ (ratio $\mathrm{CO}_{2}$ efflux $/ \mathrm{O}_{2}$ influx for tree stems) to ARQ measured from incubations of stem cores (ratio $\mathrm{CO}_{2}$ increase $/ \mathrm{O}_{2}$ decrease), by species ( $n$ individuals) in different sites. Values are means \pm SD.

fore it can be emitted to the atmosphere or being refixed during biosynthesis processes within the stem. As noted earlier, a second possibility is non-respiratory $\mathrm{O}_{2}$ uptake, e.g., by oxidases and hydroxylases that are $\mathrm{O}_{2}$-consuming enzymes, most notably used in lignin biosynthesis. However, stoichiometric analysis of this pathway shows that the $\mathrm{CO}_{2}$ produced from the sucrose that is the lignin's substrate usually exceeds the $\mathrm{O}_{2}$ consumption, so that the net effect of lignin biosyn- 


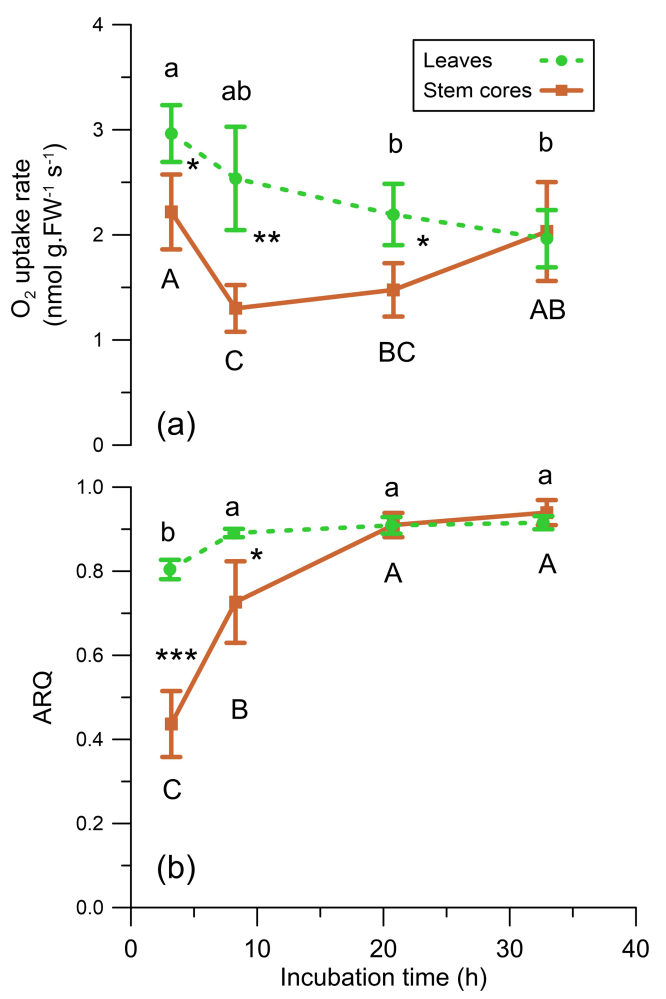

Figure 9. (a) $\mathrm{O}_{2}$ uptake rate (nmol $\mathrm{g} \mathrm{FW}^{-1} \mathrm{~s}^{-1}$ ) and (b) ARQ (ratio $\mathrm{CO}_{2}$ increase $/ \mathrm{O}_{2}$ decrease) of $Q$. ilex leaves and stem cores incubated in a closed system $(n=4)$. Values are means \pm SD. Asterisks indicate significant difference between tissues at each time step (* $P<0.05,{ }^{* *} P<0.01$, *** $P<0.0001$ in a Student's $t$ test). Different letters indicate significant difference in Tukey-Kramer HSD analysis that followed one-way analysis of variance (ANOVA) within tissue type, between time steps.

thesis should be a local increase in ARQ (Amthor, 2003). To the best of our knowledge, there are no other significant $\mathrm{O}_{2}$ consuming processes in tree stems that might affect the ARQ value.

We conclude that the low stem ARQ must be the result of $\mathrm{CO}_{2}$ being locally fixed or transported away from the site of respiration. If $\mathrm{CO}_{2}$ dissolution and DIC transport is the main export mechanism, we would expect ARQ to increase with temperature (i.e., according to solubility changes with temperature), be anti-correlated with sap flow (McGuire and Teskey, 2004; McGuire et al., 2007; Bowman et al., 2005), and to increase with height in the stem (Hölttä and Kolari, 2009). Three observations support the idea that this export mechanism controls some of the variability in ARQ. First, nighttime ARQ in $M$. domestica was indeed correlated with temperature, an expected trend given the greater temperature sensitivity of the $\mathrm{CO}_{2}$ solubility in comparison with $\mathrm{O}_{2}$ (Gevantman, 2018). Second, P. occidentalis had higher ARQ values in the upper stem position, especially during the growing season (Fig. 4). Third, relatively high ARQ values were observed at $0.2 \mathrm{~m}$ above the ground in the S. micranthum tree
(Fig. 7), which may reflect a burst of in-stem $\mathrm{CO}_{2}$ that originated from belowground respiration (McGuire and Teskey, 2004; Levy et al., 1999). However, in most of our observations ARQ did not vary as expected if $\mathrm{CO}_{2}$ dissolution and transport were the main $\mathrm{CO}_{2}$ export mechanism.

When sap flux density was measured directly, it did not explain the variation in ARQ among $Q$. ilex trees in Spain. Mean ARQ values were fairly stable over spring, summer, and winter (0.62-0.69) for Q. calliprinos in the Carmel Ridge site, while the transpiration stream probably varied greatly between seasons if related to $\Psi_{\mathrm{pd}}$. Additionally, during dormancy when no leaves were in place to force the transpiration stream, we found ARQ values $<1.0$ in four deciduous trees (black markers in Fig. 4). Sap flow rates are assumed to decline during the night, but ARQ values $<1.0$ during nighttime were measured in five species, and in most cases no nocturnal increase in ARQ in comparison to daytime values was observed (Figs. 5, 6). Thus, the temperature dependency observed for the $M$. domestica tree during the night, which explained variability in ARQ values between 0.65 and 0.75 , must be a second-order control on ARQ variability and cannot explain the big deviation from unity (according to the linear fit, an ARQ of 1.0 is expected at the unreasonable temperature of $63^{\circ} \mathrm{C}$ ). Also, the vertical transects of ARQ for $Q$. calliprinos and $S$. micranthum, including in-stem ARQ for the later (Figs. 4, 7, S5), showed no consistent pattern of ARQ increasing with stem height, unlike the ARQ increase with height measured in the $P$. occidentalis (Fig. 4).

ARQ values measured in the stem core incubations, where tissues are isolated from the influence of transport in the xylem stream, were well below 1.0 and similar to the chambers' values (Figs. 8, 9). The in-stem ARQ measured in the S. micranthum was likewise $<1.0$, but although the proximity to the xylem was greater, the values were not necessarily lower than the surface ARQ (Fig. 7). It is likely that in-stem ARQ values are influenced by dissolution in the xylem water, but the question is the following: what is the contribution of in-stem $\mathrm{CO}_{2}$ to the $\mathrm{CO}_{2}$ efflux from the stem surface? There are contradicting assessments, and the influence likely is related to wood anatomy. For example, studies of ring- and diffuse-porous species observed tight covariations of in-stem $\mathrm{CO}_{2}$ and surface efflux and have interpreted this as evidence of strong influence of in-stem $\mathrm{CO}_{2}$ concentrations (Teskey and McGuire, 2002, 2007; Steppe et al., 2007), while other studies conducted on conifers with tracheid anatomy inferred only marginal influence of in-stem processes on surface efflux (Ubierna et al., 2009; Maier and Clinton, 2006). Nevertheless, observations of covariation in in-stem $\left[\mathrm{CO}_{2}\right]$ and $\mathrm{CO}_{2}$ efflux do not necessarily represent cause-and-effect relationships (Maier and Clinton, 2006). Muhr et al. (2013) utilized the difference in ${ }^{14} \mathrm{C}$ signature of in-stem $\mathrm{CO}_{2}(5 \mathrm{~cm}$ deep) and surface efflux to estimate that $<20 \%$ of total emitted $\mathrm{CO}_{2}$ originates from the inner stem in three tropical nonconiferous tree species. Small contribution of in-stem $\mathrm{CO}_{2}$ to the surface efflux can be easily explained by the slow diffu- 
Table 2. Comparison between the calculated PEPC fixation rates required to explain measured ARQ in stem core incubations and reported PEPC fixation rates for young stems.

\begin{tabular}{|c|c|c|c|c|}
\hline & $\begin{array}{c}\mathrm{ARQ}^{\mathrm{a}} \\
\left(\mathrm{CO}_{2} \text { efflux } / \mathrm{O}_{2} \text { uptake }\right)\end{array}$ & $\begin{array}{c}\mathrm{O}_{2} \text { uptake }^{\mathrm{b}} \\
\left(\mathrm{nmol} \mathrm{g} \mathrm{DW}^{-1} \mathrm{~s}^{-1}\right)\end{array}$ & $\begin{array}{l}\text { PEPC fixation rate required } \\
\text { to explain the observed } \mathrm{ARQ}^{\mathrm{c}} \\
\left(\mathrm{nmol} \mathrm{CO}_{2} \mathrm{~g} \mathrm{DW}^{-1} \mathrm{~s}^{-1}\right)\end{array}$ & $\begin{array}{l}\text { PEPC fixation rate } \\
\left(\mathrm{nmolCg} \mathrm{DW}^{\mathrm{d}} \mathrm{s}^{-1}\right)\end{array}$ \\
\hline Quercus ilex $(n=4)$ & $0.44 \pm 0.08^{\mathrm{c}}$ & $3.84 \pm 0.30$ & 2.15 & \\
\hline Tetragastris panamensis $(n=11)$ & $0.33 \pm 0.07$ & $1.40 \pm 0.69$ & 0.93 & \\
\hline Fagus sylvatica $\mathrm{L}$. & & & & 12.6 \\
\hline Pinus sylvestris L. & & & & 16.74 \\
\hline
\end{tabular}

${ }^{a}$ Values are mean \pm SD. ${ }^{b}$ Dry weight (DW) was determined after drying in an oven at $60^{\circ} \mathrm{C}$ for 2 days. ${ }^{\mathrm{c}}$ Calculated as $\mathrm{O}_{2}$ uptake $\times(1-\mathrm{ARQ})$, which is an estimation of the flux of respired $\mathrm{CO}_{2}$ that did not diffuse out from the core, based on the assumption that carbohydrates with ARQ $=1$ are the respiratory substrate. ${ }^{\mathrm{d}}$ We calculated PEPC fixation rate of $F a g u s$ sylvatica L. with data from Berveiller and Damesin $(2008)$ as follows: PEPC activity $\left(\mathrm{nmol} \mathrm{C} \mathrm{mg}^{-1} \mathrm{chl} \mathrm{s}^{-1}\right) \times$ total $\mathrm{chl}^{\left(\mathrm{mg} \mathrm{g} \mathrm{DW}^{-1}\right)=\sim 30 \times 0.42=12.6 \mathrm{nmol} \mathrm{Cg} \mathrm{DW}-1} \mathrm{~s}^{-1}$. The chosen PEPC activity was the lowest among seasonal measurements. We calculated PEPC fixation rate of Pinus sylvestris L. with data from Ivanov et al. (2005) as follows: PEPC activity $\left(\mu \mathrm{mol} \mathrm{C} \mathrm{mg}^{-1} \mathrm{chl} \mathrm{min}^{-1}\right) \times$ total $\mathrm{chl}\left(\mu \mathrm{g} \mathrm{FW}^{-1}\right) \times \mathrm{g} \mathrm{FW} \mathrm{g} \mathrm{DW}^{-1}$ (using assumed water content of 0.5$) \times$ conversion to seconds $=1.04 \times 483.02 \times 2 \times 1 / 60=16.74 \mathrm{nmol} \mathrm{C} \mathrm{gW}^{-1} \mathrm{~s}^{-1}$. PEPC activity was measured during winter.

sion through wood of all three anatomical groups (Sorz and Hietz, 2006). The woody diffusional barrier can explain the apparent decoupling between ARQ, sap flux density, and $\Psi_{\mathrm{pd}}$ presented above. A major contribution from respiratory activity concentrated in the outer stem tissues to overall stem respiration would further reduce sap flow effects on surface fluxes (Hölttä and Kolari, 2009; Maier and Clinton, 2006; Ubierna et al., 2009).

An alternative explanation for low ARQ values could be the fixation of $\mathrm{CO}_{2}$ by biosynthesis with engagement of the enzyme PEPC, which is able to fix respired $\mathrm{CO}_{2}$. Indirect evidence for PEPC activity can be found in the increase in the ARQ values with time in our repeated incubations, while cellular activity was retained as reflected in $\mathrm{O}_{2}$ uptake rates (Fig. 9). Such a pattern may reflect a biochemical process, e.g., $\mathrm{CO}_{2}$ fixation by the enzyme PEPC, which decreases with time due to self-inhibition by the accumulation of the products (Kai et al., 1999; Huber and Edwards, 1975). PEPC fixation rates can easily explain the retained $\mathrm{CO}_{2}$, according to mass balance calculation for the stem core incubations and published PEPC fixation rates in young tree stems (Table 2). Assuming refixation is important, the fact that ARQ measured from intact stems is almost always lower than unity indicates that the fixation products, organic acids like malate and citrate or amino acids, are not inhibiting the fixation or being oxidized locally and are further metabolized or allocated elsewhere in the stem. The malate can be transported in the xylem stream as indicated by an upwards concentration increase in Acer platanoides stems (Schill et al., 1996). A possible fate of the malate might be similar to $\mathrm{C}_{4}$-like photosynthesis observed in tobacco, where xylem-transported malate contributes $\mathrm{C}$ to photosynthesis in leaves (Hibberd and Quick, 2002). Alternatively, the fixation products might be exported via the phloem. One possible sink is excretion of organic acids to the rhizosphere as root exudates, which can account for ample fraction of overall gross primary productivity (GPP) in forests (Abramoff and Finzi, 2016; Finzi et al., 2015). Indications for the transport of organic acids from upper parts of the plant to the roots have already been reported (Hoffland et al., 1992; Shane et al., 2004).

Overall, our results suggest that $\mathrm{CO}_{2}$ dissolution and removal in the xylem stream are not the main cause of the low ARQ values that are common to the trees we measured. We speculate the observed ARQ values resulted by PEPC refixation, with possible cumulative effects of some dissolution and transport, partial lipid metabolism, and some nonrespiratory $\mathrm{O}_{2}$ consumption. Corticular photosynthesis may theoretically influence ARQ, but in a complex manner; with an assumed $\mathrm{O}_{2} / \mathrm{CO}_{2}$ exchange ratio of 1.0 and given that all other processes yield ARQ $<1.0$, the photosynthesis will reduce the $\mathrm{CO}_{2}$ and $\mathrm{O}_{2}$ concentration gradients between stem and atmosphere in the same absolute numbers, which will cause a further ARQ decrease. However, in our measurements photosynthesis was prevented by shading the measured stem surface. Additionally, most evidence for significant corticular photosynthesis comes from twigs and young stems (Pfanz et al., 2002; Ávila et al., 2014), while stems in the current study were mature. Wood anatomy may further impact ARQ by modifying the contribution of internal stem processes on surface fluxes. The numerous mechanisms potentially responsible for ARQ probably varied with the broad range of species and wood anatomies we investigated. Further research to pursue the potential role of PEPC, including direct measurement of PEPC activity, would be needed to assess whether PEPC plays a role in lowering ARQ values to the levels observed. To complete the stem $\mathrm{C}$ balance, additional evaluation of the relations between the in-stem and the stem surface fluxes is also needed, as well as analysis of how organic and amino acids vary in the stem.

\subsection{Implications of low ARQ}

From a whole ecosystem perspective, if respired $\mathrm{CO}_{2}$ in the stem returns to the atmosphere elsewhere (e.g., in the soil, canopy), the overall ecosystem-atmosphere $\mathrm{C}$ fluxes will not be affected, and high ARQ associated with the release of the transported $\mathrm{CO}_{2}$ will balance the low ARQ in the stem. Such 
ARQ $>1.0$ values are expected in the rhizosphere where organic acids are decomposed. In the canopy, greater refixation of internal $\mathrm{C}$ is expected to increase the photosynthetically oxidative ratio $\left(\mathrm{O}_{2}\right.$ produced $/ \mathrm{CO}_{2}$ consumed $)$, as the internally transported $\mathrm{C}$ replaces the atmospheric $\mathrm{CO}_{2}$ when assimilation is measured. Additionally, such internal transport can (i) cause a discrepancy between the measured aboveground and belowground $\mathrm{CO}_{2}$ effluxes and the locations where respiration is actually occurring (Aubrey and Teskey, 2009) and (ii) lead to false attribution of respiration responses to environmental conditions. Moreover, the different long-term temperature sensitivity of $\mathrm{CO}_{2}$ efflux and $\mathrm{O}_{2}$ influx is of interest and might explain part of the gap between modeled and observed $Q_{10}$ values of tree respiration (Griffin and Prager, 2017). For example, decrease in ARQ with rising temperature (due to higher PEPC activity for example) might result in a slow increase in $\mathrm{CO}_{2}$ efflux, whereas the respiration rate $\left(\mathrm{O}_{2}\right.$ uptake $)$ is actually increasing sharply, together with the internal $\mathrm{C}$ flux. Future studies should determine how temperature and nutrients control long-term changes in ARQ and aim to identify the biochemical process that control the low ARQ reported by the current study.

Data availability. Data used in this study can be found in figures, tables, and in the Supplement.

Supplement. The supplement related to this article is available online at: https://doi.org/10.5194/bg-16-177-2019-supplement.

Author contributions. $\mathrm{BH}$ and AA planned and designed the research. BH performed most of the ARQ sampling and analysis and led the writing of the manuscript. JM, NK, and SET carried out the field work in Brazil, and MSC carried out the field work in the USA. PY measured shoot water potential. SJW designed the longterm experiment in the Republic of Panama. GM, OPP, MM, and AC contributed to the campaign in Spain. OPP measured the sap flux density. JMG and YO contributed to the campaigns in Carmel Ridge. TW contributed to the campaigns in Spain and Jerusalem. JM, SET, SJW, GM, OPP, MM, JMG, and AA contributed to the discussion and writing.

Competing interests. The authors declare that they have no conflict of interest.

Acknowledgements. This research was funded by the GermanIsraeli Foundation for Scientific and Development (no. 1334 12016), and by a Ring Foundation grant. Boaz Hilman was partly funded by the Advanced School for Environmental Studies and by the Canadian Friends of the Hebrew University. Mirco Migliavacca and Oscar Pérez-Priego acknowledge the Alexander von Humboldt Foundation for supporting the research activities of the MANIP project with the Max Planck Prize to Markus Reichstein. We thank
Avihay Berry for assistance with field work at Jerusalem, Itsik Simchayov for technical support, the Ramat Hanadiv Nature Park for logistic assistance, the Jerusalem Botanical Gardens in Givat Ram and especially Ori Fragman-Sapir and Ofri Bar for facilitating this research, and Rufino Gonzales and Omar Hernandez for assistance with field work at the Barro Colorado Nature Monument.

The article processing charges for this open-access publication were covered by the Max Planck Society.

Edited by: Paul Stoy

Reviewed by: two anonymous referees

\section{References}

Abramoff, R. Z. and Finzi, A. C.: Seasonality and partitioning of root allocation to rhizosphere soils in a midlatitude forest, Ecosphere, 7, e01547, https://doi.org/10.1002/ecs2.1547, 2016.

Amthor, J. S.: Efficiency of lignin biosynthesis: a quantitative analysis, Ann. Bot.-London, 91, 673-695, https://doi.org/10.1093/aob/mcg073, 2003.

Angert, A. and Sherer, Y.: Determining the relationship between tree-stem respiration and $\mathrm{CO}_{2}$ efflux by $\delta \mathrm{O}_{2} / \mathrm{Ar}$ measurements, Rapid Commun. Mass Sp., 25, 1752-1756, https://doi.org/10.1002/Rcm.5042, 2011.

Angert, A., Muhr, J., Negron Juarez, R., Alegria Muñoz, W., Kraemer, G., Ramirez Santillan, J., Barkan, E., Mazeh, S., Chambers, J. Q., and Trumbore, S. E.: Internal respiration of Amazon tree stems greatly exceeds external $\mathrm{CO}_{2}$ efflux, Biogeosciences, 9, 4979-4991, https://doi.org/10.5194/bg-9-4979-2012, 2012.

Aranda, I., Gil, L., and Pardos, J. A.: Seasonal changes in apparent hydraulic conductance and their implications for water use of European beech (Fagus sylvatica L.) and sessile oak [Quercus petraea (Matt.) Liebl] in South Europe, Plant Ecol., 179, 155167, https://doi.org/10.1007/s11258-004-7007-1, 2005.

Aubrey, D. P. and Teskey, R. O.: Root-derived $\mathrm{CO}_{2}$ efflux via xylem stream rivals soil $\mathrm{CO}_{2}$ efflux, New Phytol., 184, 35-40, https://doi.org/10.1111/j.1469-8137.2009.02971.x, 2009.

Ávila, E., Herrera, A., and Tezara, W.: Contribution of stem $\mathrm{CO}_{2}$ fixation to whole-plant carbon balance in nonsucculent species, Photosynthetica, 52, 3-15, 2014.

Berveiller, D. and Damesin, C.: Carbon assimilation by tree stems: potential involvement of phosphoenolpyruvate carboxylase, Trees-Struct. Funct., 22, 149-157, https://doi.org/10.1007/s00468-007-0193-4, 2008.

Bloemen, J., McGuire, M. A., Aubrey, D. P., Teskey, R. O., and Steppe, K.: Transport of root-respired $\mathrm{CO}_{2}$ via the transpiration stream affects aboveground carbon assimilation and $\mathrm{CO}_{2}$ efflux in trees, New Phytol., 197, 555-565, https://doi.org/10.1111/j.1469-8137.2012.04366.x, 2013.

Bowman, W. P., Barbour, M. M., Turnbull, M. H., Tissue, D. T., Whitehead, D., and Griffin, K. L.: Sap flow rates and sapwood density are critical factors in within- and between-tree variation in $\mathrm{CO}_{2}$ efflux from stems of mature Dacrydium cupressinum trees, New Phytol., 167, 815-828, doi10.1111/j.1469-8137.2005.01478.x, 2005.

Bucci, S. J., Goldstein, G., Meinzer, F. C., Franco, A. C., Campanello, P., and Scholz, F. G.: Mechanisms contribut- 
ing to seasonal homeostasis of minimum leaf water potential and predawn disequilibrium between soil and plant water potential in Neotropical savanna trees, Trees, 19, 296-304, https://doi.org/10.1007/s00468-004-0391-2, 2005.

Carbone, M. S., Czimczik, C. I., Keenan, T. F., Murakami, P. F., Pederson, N., Schaberg, P. G., Xu, X., and Richardson, A. D.: Age, allocation and availability of nonstructural carbon in mature red maple trees, New Phytol., 200, 1145-1155, https://doi.org/10.1111/nph.12448, 2013.

De Vries, F. W. T. P., Brunsting, A. H. M., and Van Laar, H. H.: Products, requirements and efficiency of biosynthesis a quantitative approach, J. Theor. Biol., 45, 339-377, https://doi.org/10.1016/0022-5193(74)90119-2, 1974.

Finzi, A. C., Abramoff, R. Z., Spiller, K. S., Brzostek, E. R., Darby, B. A., Kramer, M. A., and Phillips, R. P.: Rhizosphere processes are quantitatively important components of terrestrial carbon and nutrient cycles, Glob. Change Biol., 21, 2082-2094, https://doi.org/10.1111/gcb.12816, 2015.

Fischer, S., Hanf, S., Frosch, T., Gleixner, G., Popp, J., Trumbore, S., and Hartmann, H.: Pinus sylvestris switches respiration substrates under shading but not during drought, New Phytol., 207, 542-550, https://doi.org/10.1111/nph.13452, 2015.

Gessler, A., Tcherkez, G., Karyanto, O., Keitel, C., Ferrio, J. P., Ghashghaie, J., Kreuzwieser, J., and Farquhar, G. D.: On the metabolic origin of the carbon isotope composition of $\mathrm{CO}_{2}$ evolved from darkened light-acclimated leaves in Ricinus communis, New Phytol., 181, 374-386, https://doi.org/10.1111/j.1469-8137.2008.02672.x, 2009.

Gevantman, L. H.: Solubility of Selected Gases in Water, in: CRC Handbook of Cemistry and Physics, edited by: Rumble, J. R., CRC press/Taylor and Francis, Boca Raton, FL, 2018.

Griffin, K. L. and Prager, C. M.: Where does the carbon go? Thermal acclimation of respiration and increased photosynthesis in trees at the temperate-boreal ecotone, Tree Physiol., 37, 281284, https://doi.org/10.1093/treephys/tpw133, 2017.

Hanf, S., Fischer, S., Hartmann, H., Keiner, R., Trumbore, S., Popp, J., and Frosch, T.: Online investigation of respiratory quotients in Pinus sylvestris and Picea abies during drought and shading by means of cavity-enhanced Raman multi-gas spectrometry, Analyst, 140, 4473-4481, https://doi.org/10.1039/c5an00402k, 2015.

Hartmann, H. and Trumbore, S.: Understanding the roles of nonstructural carbohydrates in forest trees - from what we can measure to what we want to know, New Phytol., 211, 386-403, https://doi.org/10.1111/nph.13955, 2016.

Hibberd, J. M. and Quick, W. P.: Characteristics of $\mathrm{C}_{4}$ photosynthesis in stems and petioles of $\mathrm{C} 3$ flowering plants, Nature, 415, 451-454, https://doi.org/10.1038/415451a, 2002.

Hilman, B. and Angert, A.: Measuring the ratio of $\mathrm{CO}_{2}$ efflux to $\mathrm{O}_{2}$ influx in tree stem respiration, Tree Physiol., 36, 1422, https://doi.org/10.1093/treephys/tpw057, 2016.

Hoch, G., Richter, A., and Körner, C.: Non-structural carbon compounds in temperate forest trees, Plant Cell Environ., 26, 10671081, https://doi.org/10.1046/j.0016-8025.2003.01032.x, 2003.

Hoffland, E., Van Den Boogaard, R., Nelemans, J., and Findenegg, G.: Biosynthesis and root exudation of citric and malic acids in phosphate-starved rape plants, New Phytol., 122, 675-680, https://doi.org/10.1111/j.1469-8137.1992.tb00096.x, 1992.
Höll, W.: Dark $\mathrm{CO}_{2}$ fixation by cell-free preparations of the wood of Robinia pseudoacacia, Can. J. Bot., 52, 727-734, https://doi.org/10.1139/b74-094, 1974.

Hölttä, T. and Kolari, P.: Interpretation of stem $\mathrm{CO}_{2}$ efflux measurements, Tree Physiol., 29, 1447-1456, https://doi.org/10.1093/treephys/tpp073, 2009.

Huber, S. C. and Edwards, G. E.: Inhibition of phosphoenolpyruvate carboxylase from $\mathrm{C}_{4}$ plants by malate and aspartate, Can. J. Bot., 53, 1925-1933, https://doi.org/10.1139/b75-216, 1975.

Ivanov, A. G., Krol, M., Sveshnikov, D., Malmberg, G., Gardeström, P., Hurry, V., Öquist, G., and Huner, N. P. A.: Characterization of the photosynthetic apparatus in cortical bark chlorenchyma of Scots pine, Planta, 223, 1165, https://doi.org/10.1007/s00425-005-0164-1, 2005.

Kai, Y., Matsumura, H., Inoue, T., Terada, K., Nagara, Y., Yoshinaga, T., Kihara, A., Tsumura, K., and Izui, K.: Threedimensional structure of phosphoenolpyruvate carboxylase: a proposed mechanism for allosteric inhibition, P. Natl. Acad. Sci. USA, 96, 823-828, 1999.

Lambers, H., Chapin III, F. S., and Pons, T. L.: Plant Physiological Ecology, 2nd Edn., Springer, New York, NY, 610 pp., 2008.

Levy, P. E., Meir, P., Allen, S. J., and Jarvis, P. G.: The effect of aqueous transport of $\mathrm{CO}_{2}$ in xylem sap on gas exchange in woody plants, Tree Physiol., 19, 53-58, https://doi.org/10.1093/treephys/19.1.53, 1999.

Maier, C. A. and Clinton, B. D.: Relationship between stem $\mathrm{CO}_{2}$ efflux, stem sap velocity and xylem $\mathrm{CO}_{2}$ concentration in young loblolly pine trees, Plant Cell Environ., 29, 1471-1483, https://doi.org/10.1111/j.1365-3040.2006.01511.x, 2006.

Massman, W. J.: A review of the molecular diffusivities of $\mathrm{H}_{2} \mathrm{O}$, $\mathrm{CO}_{2}, \mathrm{CH}_{4}, \mathrm{CO}, \mathrm{O}_{3}, \mathrm{SO}_{2}, \mathrm{NH}_{3}, \mathrm{~N}_{2} \mathrm{O}, \mathrm{NO}$, and $\mathrm{NO}_{2}$ in air, $\mathrm{O}_{2}$ and $\mathrm{N}_{2}$ near STP, Atmos. Environ., 32, 1111-1127, https://doi.org/10.1016/s1352-2310(97)00391-9, 1998.

McGuire, M. A. and Teskey, R. O.: Estimating stem respiration in trees by a mass balance approach that accounts for internal and external fluxes of $\mathrm{CO}_{2}$, Tree Physiol., 24, 571-578, https://doi.org/10.1093/treephys/24.5.571, 2004.

McGuire, M. A., Cerasoli, S., and Teskey, R. O.: $\mathrm{CO}_{2}$ fluxes and respiration of branch segments of sycamore (Platanus occidentalis L.) examined at different sap velocities, branch diameters, and temperatures, J. Exp. Bot., 58, 2159-2168, https://doi.org/10.1093/jxb/erm069, 2007.

McGuire, M. A., Marshall, J. D., and Teskey, R. O.: Assimilation of xylem-transported ${ }^{13} \mathrm{C}$-labelled $\mathrm{CO}_{2}$ in leaves and branches of sycamore (Platanus occidentalis L.), J. Exp. Bot., 60, 38093817, https://doi.org/10.1093/jxb/erp222, 2009.

Muhr, J., Angert, A., Negrón-Juárez, R. I., Muñoz, W. A., Kraemer, G., Chambers, J. Q., and Trumbore, S. E.: Carbon dioxide emitted from live stems of tropical trees is several years old, Tree Physiol., https://doi.org/10.1093/treephys/tpt049, 2013.

Perez-Priego, O., El-Madany, T. S., Migliavacca, M., Kowalski, A. S., Jung, M., Carrara, A., Kolle, O., Martín, M. P., Pacheco-Labrador, J., Moreno, G., and Reichstein, M.: Evaluation of eddy covariance latent heat fluxes with independent lysimeter and sapflow estimates in a Mediterranean savannah ecosystem, Agr. Forest Meteorol., 236, 87-99, https://doi.org/10.1016/j.agrformet.2017.01.009, 2017.

Pfanz, H., Aschan, G., Langenfeld-Heyser, R., Wittmann, C., and Loose, M.: Ecology and ecophysiology of tree stems: corticu- 
lar and wood photosynthesis, Naturwissenschaften, 89, 147-162, https://doi.org/10.1007/s00114-002-0309-z, 2002.

Plaxton, W. C. and Podestá, F. E.: The Functional Organization and Control of Plant Respiration, Crit. Rev. Plant Sci., 25, 159-198, https://doi.org/10.1080/07352680600563876, 2006.

Powers, E. M. and Marshall, J. D.: Pulse labeling of dissolved ${ }^{13} \mathrm{C}$ carbonate into tree xylem: developing a new method to determine the fate of recently fixed photosynthate, Rapid Commun. Mass Sp., 25, 33-40, https://doi.org/10.1002/rcm.4829, 2011.

Pruyn, M. L., Gartner, B. L., and Harmon, M. E.: Respiratory potential in sapwood of old versus young ponderosa pine trees in the Pacific Northwest, Tree Physiol., 22, 105-116, 2002.

Salomón, R. L., De Schepper, V., Valbuena-Carabaña, M., Gil, L., and Steppe, K.: Daytime depression in temperature-normalised stem $\mathrm{CO}_{2}$ efflux in young poplar trees is dominated by low turgor pressure rather than by internal transport of respired $\mathrm{CO}_{2}$, New Phytol., 217, 586-598, https://doi.org/10.1111/nph.14831, 2018.

Sayer, E. J. and Tanner, E. V.: Experimental investigation of the importance of litterfall in lowland semi-evergreen tropical forest nutrient cycling, J. Ecol., 98, 1052-1062, https://doi.org/10.1111/j.1365-2745.2010.01680.x, 2010.

Schill, V., Hartung, W., Orthen, B., and Weisenseel, M. H.: The xylem sap of maple (Acer platanoides) trees - sap obtained by a novel method shows changes with season and height, J. Exp. Bot., 47, 123-133, https://doi.org/10.1093/jxb/47.1.123, 1996.

Scholander, P. F., Bradstreet, E. D., Hemmingsen, E. A., and Hammel, H. T.: Sap Pressure in Vascular Plants: Negative hydrostatic pressure can be measured in plants, Science, 148, 339-346, https://doi.org/10.1126/science.148.3668.339, 1965.

Shane, M. W., Cramer, M. D., Funayama-Noguchi, S., Cawthray, G. R., Millar, A. H., Day, D. A., and Lambers, H.: Developmental Physiology of Cluster-Root Carboxylate Synthesis and Exudation in Harsh Hakea. Expression of Phosphoenolpyruvate Carboxylase and the Alternative Oxidase, Plant Physiol., 135, 549560, https://doi.org/10.1104/pp.103.035659, 2004.

Sinnott, E. W.: Factors Determining Character and Distribution of Food Reserve in Woody Plants, Bot. Gaz., 66, 162-175, https://doi.org/10.1086/332321, 1918.
Sorz, J. and Hietz, P.: Gas diffusion through wood: implications for oxygen supply, Trees-Struct. Funct., 20, 34-41, https://doi.org/10.1007/s00468-005-0010-x, 2006.

Steppe, K., Saveyn, A., McGuire, M. A., Lemeur, R., and Teskey, R. O.: Resistance to radial $\mathrm{CO}_{2}$ diffusion contributes to betweentree variation in $\mathrm{CO}_{2}$ efflux of Populus deltoides stems, Funct. Plant Biol., 34, 785-792, https://doi.org/10.1071/FP07077, 2007.

Teskey, R. and McGuire, M.: Measurement of stem respiration of sycamore (Platanus occidentalis L.) trees involves internal and external fluxes of $\mathrm{CO}_{2}$ and possible transport of $\mathrm{CO}_{2}$ from roots, Plant Cell Environ., 30, 570-579, https://doi.org/10.1111/j.13653040.2007.01649.x, 2007.

Teskey, R. O. and McGuire, M. A.: Carbon dioxide transport in xylem causes errors in estimation of rates of respiration in stems and branches of trees, Plant Cell Environ., 25, 1571-1577, https://doi.org/10.1046/j.1365-3040.2002.00961.x, 2002.

Teskey, R. O., Saveyn, A., Steppe, K., and McGuire, M. A.: Origin, fate and significance of $\mathrm{CO}_{2}$ in tree stems, New Phytol., 177, 17-32, https://doi.org/10.1111/j.1469-8137.2007.02286.x, 2008.

Trumbore, S. E., Angert, A., Kunert, N., Muhr, J., and Chambers, J. Q.: What's the flux? Unraveling how $\mathrm{CO}_{2}$ fluxes from trees reflect underlying physiological processes, New Phytol., 197, 353 355, https://doi.org/10.1111/nph.12065, 2013.

Ubierna, N., Kumar, A. S., Cernusak, L. A., Pangle, R. E., Gag, P. J., and Marshall, J. D.: Storage and transpiration have negligible effects on $\delta^{13} \mathrm{C}$ of stem $\mathrm{CO}_{2}$ efflux in large conifer trees, Tree Physiol., 29, 1563-1574, 2009.

Wright, S. J., Yavitt, J. B., Wurzburger, N., Turner, B. L., Tanner, E. V. J., Sayer, E. J., Santiago, L. S., Kaspari, M., Hedin, L. O., Harms, K. E., Garcia, M. N., and Corre, M. D.: Potassium, phosphorus, or nitrogen limit root allocation, tree growth, or litter production in a lowland tropical forest, Ecology, 92, 1616-1625, https://doi.org/10.1890/10-1558.1, 2011.

Yang, J., He, Y., Aubrey, D. P., Zhuang, Q., and Teskey, R. O.: Global patterns and predictors of stem $\mathrm{CO}_{2}$ efflux in forest ecosystems, Glob. Change Biol., 22, 1433-1444, https://doi.org/10.1111/gcb.13188, 2016. 